\title{
The Morphology and Physiology of the Genus Eidamia.
}

\author{
BY
}

\begin{abstract}
A. S. HORNE, D.Sc., and H. S. WILliAMSON, B.Sc.
\end{abstract}
(From the Department of Plant Physiology and Pathology, Imperial College of Sience and Technology.)

With twenty-three Figures in the Text.

Contents.

I. INTRODUCTION

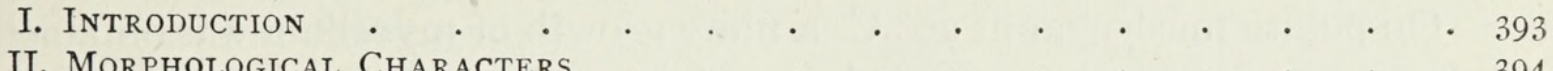

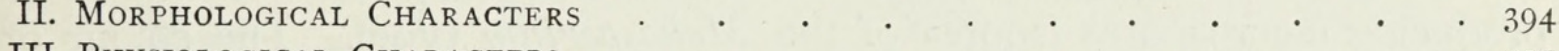

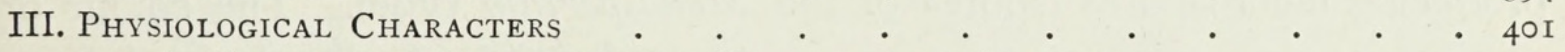

A. Growth in Carbohydrate, Protein, and Asparagin . . . . 40 i

B. Growth Limitation in Relation to Hydrogen-ion Concentration • 408

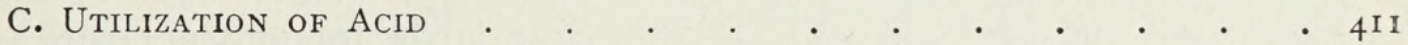

D. Growth on Agar with Organic Acid in Various Concentrations • 4i 2

E. Growth on Potato Extract Agar with Organic Acid in Various Concentrations . . . . . . . . . . . . . 4 . . .

F. Growth in Equimolar Solutions of Organic Acids . . . $44^{21}$

G. Colour Production in Media containing Gallic or Tannic Acid • 424

H. General Conclusions on Growth in Relation to Acids . • . 425

IV. Systematic Position and Specific Descriptions . . . . . . . $\quad .426$

V. Summary $\cdot$ •

\section{INTRODUCTION.}

THE genus Eidamia was founded by Lindau (11) to include fungi which bear a general resemblance to Aspergillus, but differ from it in possessing not only conidia but also spores of a second type. These spores are larger than the conidia and are borne singly on lateral branches as in certain species of Monosporium. This genus has hitherto consisted of one species only; Eidamia acremonioides, Harz, originally described as Monosporium acremonioides by Harz in I87I, and as Papulaspora aspergilliformis by Eidam (6) in 1883 .

Comparatively recently the writers, working concurrently on different problems, obtained two fungi which, although differing from one another and from Eidamia acremonioides somewhat widely, nevertheless agree with Eidamia in possessing spores of the Monosporium type in addition to their

[Annals of Botany, Vol. XXXVII. No. CXLVII. July, 1923.] 
conidial fructifications. The two new species differ from $E$. acremonioides chiefly in the form of the conidiophores, which are irregularly branched and not typically swollen at the apex, and in the fact that the second type of spore is uncoloured, whereas it is brown in E. acremonioides. Since the two species agree more closely with Eidamia acremonioides than with any allied fungus, they have been named Eidamia viridescens, n. sp., and Eidamia catemulata, n. sp., respectively.

\section{Morphological Characters.}

I. Eidamia acremonioides; syn. Monosporium acremonioides, Harz, Papulaspora aspergilliformis, Eidam.

A culture on rice was obtained from the fungus collection at Amsterdam. The growth on rice was filmy and coloured brown, due to the number of large brown spores produced. Single spore cultures were obtained from gelatine dilutions and used to subculture on a variety of media.

On potato mush agar at $20^{\circ} \mathrm{C}$. a filmy growth of mycelium was obtained producing macrospores (spores of the Monosporium type). The colour of the culture gradually changed from

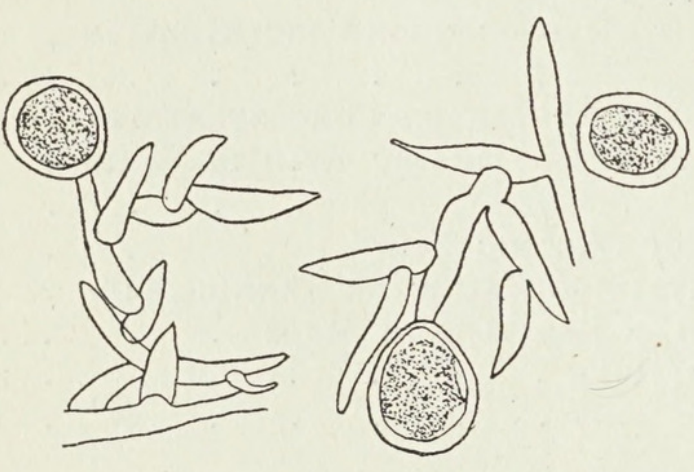

FIG. I. E. acremonioides. Mycelium, showing typical branching and macrospores. $\times 390$. snuff-brown (see Ridgeway's ' Colour Standards' for nomenclature adopted) to Vandyke brown as the spores matured. These spores are large, brown, and ovoid, resembling those described for Monosporium by Delacroix. They are borne singly on lateral branchẹs of variable length, and these are themselves branched often at a right or obtuse angle. These spores are thick-walled and vary in size from $\mathrm{I} 2 \mu \times 10 \mu$ to $34 \mu \times 28 \mu$, or even reach $40 \mu \times 34 \mu$ on potato glucose agar. Fig. I shows the typical branching and the macrospores of Eidamia acremonioides. Macrospores were the only spores produced when the fungus was grown on rice at $20^{\circ} \mathrm{C}$, , potato slab at $25^{\circ} \mathrm{C}$., and potato mush agar at $30^{\circ} \mathrm{C}$.

The conidiophores are long, averaging $140 \mu$ in length, terminating in a swollen head of about $24 \mu$ in diameter on which are borne the sterigmata and conidia. The sterigmata are swollen towards the base and pointed at the apex, being $6 \mu$ in length and $4 \mu$ in basal width. On these the conidia arise typically in short chains, though often they appear to cling to the pointed ends of the sterigmata in groups (Fig. 2). The conidia are hyaline, circular, or egg-shaped, being $\mathrm{I} \cdot 5 \mu$ to $2 \mu$ in diameter. 
The aspergilliform head of conidia is typical for this fungus, but on potato extract agar every stage between this form and sterigmata borne singly on a lateral hypha occurred (Fig. 3). This variation was noted by Bainier (1) in his description of Papulaspora aspergilliformis, and by Eidam (6) in his description of Helicosporangium parasiticum, the figures of which markedly resemble those found by the writers in Eidamia acremonioides on potato extract agar.

The peculiar growths (bulbils) figured by Rabenhorst for E.acremonioides were not observed in the culture media employed in this investigation.

Growth was obtained on potato extract agar, potato mush agar, potato glucose agar, rice, in a 2 per cent. solution of peptone (where many irregular

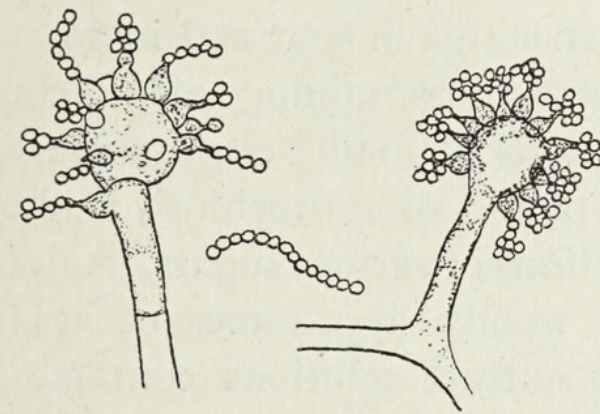

FIG. 2. E. acremonioides. Conidiophores showing chains and groups of conidia. $\times 39$.
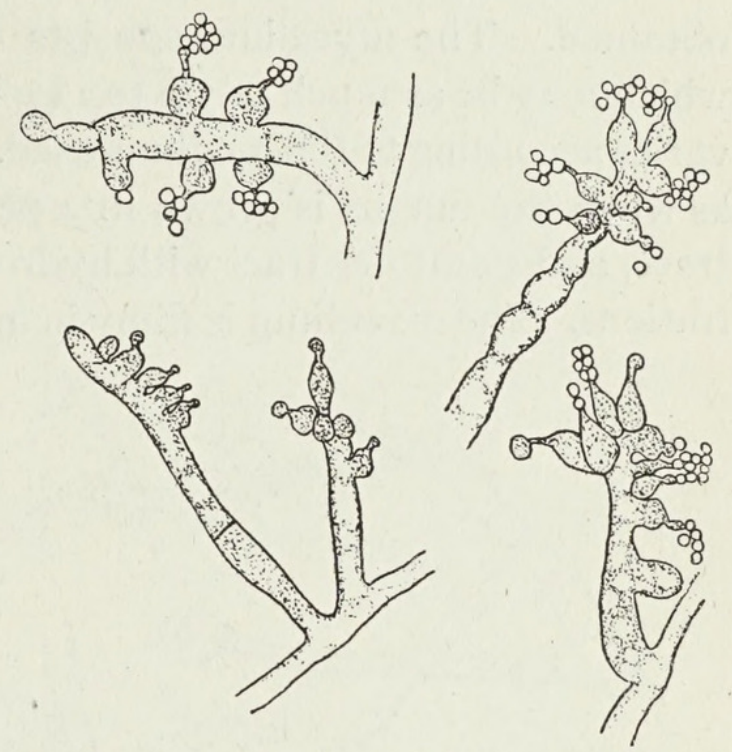

FIG. 3. E. acremonioides. Types of conidiophores produced when grown on potato extract agar at $20^{\circ} \mathrm{C}$. for four days. $\times 39{ }^{\circ}$.

short branches occurred on the mycelium, probably representing incipient conidiophores, and the majority of the macrospores were hyaline), and 2 per cent. peptone containing a 4 per cent. concentration of glucose. Slight growth also was visible in solutions of sucrose and maltose and a synthetic nutrient agar. With potato extract agar and certain percentages of citric acid the growth was tufted and exhibited considerable sporulation with macrospores at the higher concentrations; whilst on neutralized potato extract a thick scum-like growth was produced, dotted with brown macrospores and conidia in chains and groups.

The colour of the growth produced in various media varied with the age of the culture and temperature conditions. At $20^{\circ} \mathrm{C}$. the initial colour was light brown, changing to snuff-brown and finally Vandyke brown, whereas at $25^{\circ} \mathrm{C}$. the initial colour was, as a rule, pinkish buff or pinkish cinnamon; and where growth occurred at $30^{\circ} \mathrm{C}$. the colour was usually ochraceous salmon. 
Optimum growth in all the culture media employed was obtained at $20^{\circ} \mathrm{C}$, with very little growth at $30^{\circ} \mathrm{C}$. On synthetic nutrient agar no growth occurred at $25^{\circ} \mathrm{C}$. or $30^{\circ} \mathrm{C}$.

The production of conidia and the colour of the macrospores are affected by temperature. At $30^{\circ} \mathrm{C}$. no conidia were observed and the majority of the macrospores were hyaline, whilst at $20^{\circ}$ and $25^{\circ} \mathrm{C}$. numerous conidia and brown macrospores were formed.

\section{Eidamia viridescens, n. sp.}

This fungus was isolated from rotting apples and single spore cultures obtained. The mycelium consists of colourless septate branched hyphae, which may be as much as $7 \mu$ to I I $\mu$ in width. The character of the mycelium varies according to the medium used. It may have a gelatinous consistency, as when the fungus is grown in 2 per cent. peptone, neutralized potato extract, and potato extract with hydrochloric acid in N/I00 or N/1000 concentrations. The mycelium is filmy in appearance in I per cent. concentrations of

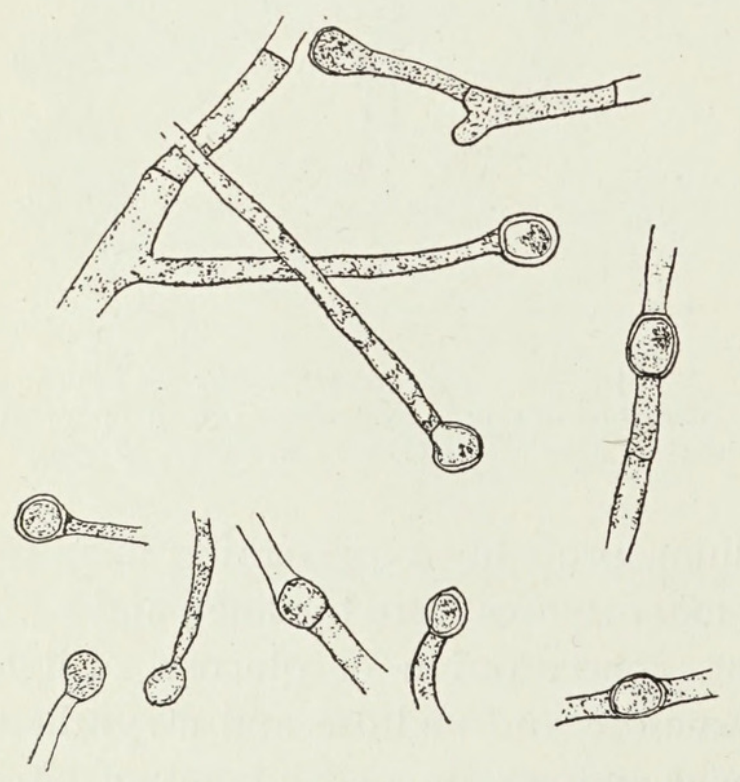

FIG. 4. E. viridescens. Terminal and intercalary macrospores on potato extract agar at $25^{\circ} \mathrm{C} . \times 390$. wheaten starch in agar and in potato extract agar, containing various concentrations of malic, citric, tartaric, gallic, tannic, or hydrochloric acid or in solutions of various sugars. A flocculent woolly appearance occurs in potato extract solutions containing gallic or malic acid in $I .5$ or 2 per cent. concentrations.

Two kinds of spores are produced, hyaline macrospores and conidia. The macrospores are thickwalled, circular, or ovoid, varying in size from II $\mu \times 8 \mu$, I $3 \mu \times 9 \mu$, to I $2 \mu$ in diameter. They are borne singly at the end of lateral branches or may be intercalary (Fig. 4). These are developed in from 3 to 8 days after inoculation according to the medium employed. Macrospores were found in all the culture media employed except prune agar at $20^{\circ} \mathrm{C}$. and synthetic nutrient agar at $20^{\circ} \mathrm{C}$., though a few were present on synthetic nutrient agar at $25^{\circ} \mathrm{C}$. after eight days' growth.

The conidiophores are, as a rule, branched structures with the sterigmata borne either in groups or singly along the branches (Figs. 5 and 6). The sterigmata resemble those of $E$. acremonioides in structure, being broad 
Fragmentation and the production of swollen cells occurred in $\mathrm{N} / \mathrm{r} 00$ and $\mathrm{N} / 1000 \mathrm{HCl}$, in solutions of sugars, and in soluble pectin. The optimum temperature for growth lies between $20^{\circ}$ and $25^{\circ} \mathrm{C}$., no growth being obtained at $30^{\circ} \mathrm{C}$.

Bramley's seedling apples were inoculated with E. viridescens kept at $20^{\circ} \mathrm{C}$. and examined after eight days. Very little surface growth was visible, but definite growth into the apple occurred, showing that the fungus is capable of parasitizing the living cell.

\section{Eidamia catemulata, n. sp.}

This fungus was isolated from a seasoned specimen of the heartwood of Quercus robur. Single spore cultures were obtained and all sub-cultures made from them.

The mycelium consists of colourless septate branched hyphae varying from $3 \mu$ to I I $\mu$ in width. These hyphae are usually thin-walled, but thickwalled hyphae do occur when the fungus is grown on certain media, such as potato glucose agar or prune agar. The mycelium usually forms a close thin felt, though it may be filmy, when grown on gallic or citric acid agar and sugars such as sucrose, lactose, and maltose ; or flocculent, when grown on $\mathrm{I} .5$ and 2 per cent. tannic or gallic acid agar, and potato extract with various concentrations of malic acid ; or of a sub-leathery consistency, when grown on 2 per cent. peptone with 4 per cent. glucose. In potato extract containing $\mathrm{N} / \mathrm{IO}, \mathrm{N} / \mathrm{I} 00$, or $\mathrm{N} / 1000$ concentrations of $\mathrm{HCl}$ the hyphae show many swollen bulbous cells, some of which produce sterigmata and conidia (Fig. 7).

Two kinds of spores are produced, hyaline macrospores and conidia. The macrospores are borne directly on the hyphae or at the end of a short branch, or may be intercalary. They often occur in pairs and are thickwalled, round, or pear-shaped, with well-marked contents (Fig. 8). They vary in size from $7.5 \mu \times 8.5 \mu$ to $14 \mu \times 10 \mu$, or may be even $18 \mu$ in diameter. These hyaline spores occur on all the culture media employed when kept at $20^{\circ}$ or $25^{\circ} \mathrm{C}$.: they are less numerous or absent at $30^{\circ} \mathrm{C}$.

The conidia are borne in long chains (containing up to Ioo spores in each) on sterigmata arising directly from an aerial hypha, or on short branches from such a hypha, or on a more complicated conidiophore where a branch from the mycelium has again branched several times, forming one to several sterigmata on each branch (Fig. 9). Occasionally, several sterigmata arise from a slightly swollen short branch (Fig. I0), and sometimes a Penicillium type of conidiophore may occur (Fig. II). The sterigmata are slender, slightly swollen at the base, and vary in size from $8 \mu$ to I $6 \mu$ in length and I $\mu$ to $2.5 \mu$ in width at the base.

The conidia are yellow in colour, narrow to broadly elliptical, pointed 
at both ends, and vary in size from $4 \mu \times 2 \mu$ to $7 \mu \times 3.5 \mu$. Under certain conditions the conidia are disposed in groups: the conidium at the end of a chain tilts over until it rests sideways on the one below, and this process continues until all the spores are arranged in a group at the tip of

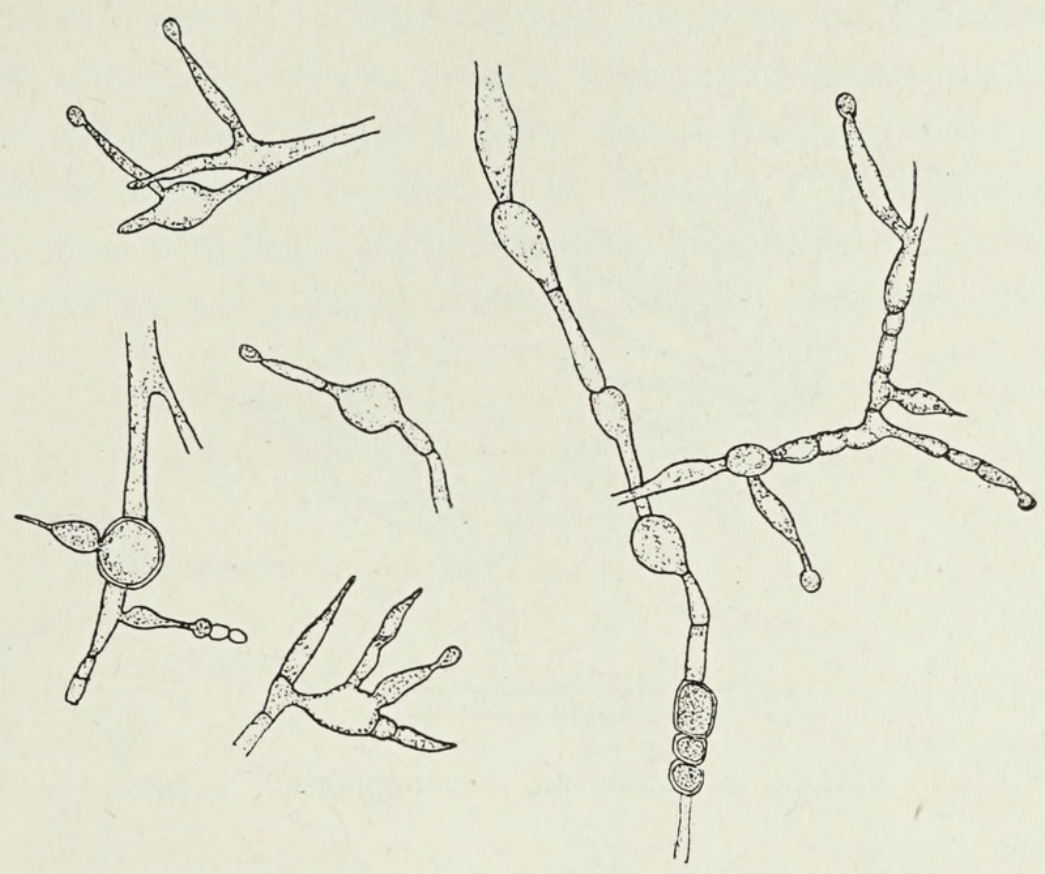

Fig. 7. E. catemulata. Swollen cells producing sterigmata; from a culture on $\mathrm{N} / 100 \mathrm{HCl}$ potato extract agar at $20^{\circ} \mathrm{C} . \quad \times 39^{\circ}$.

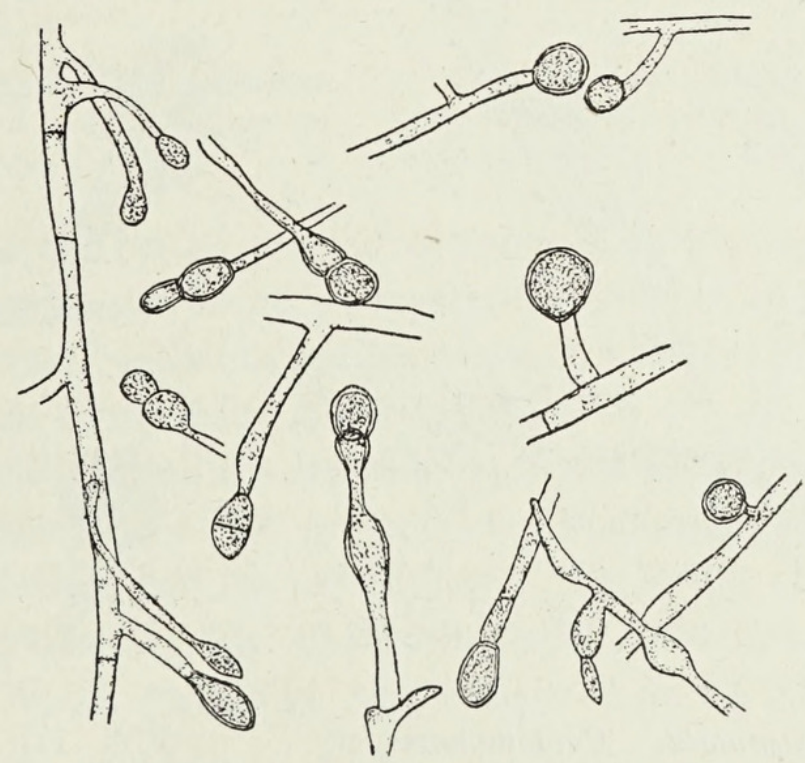

FIG. 8. E. catemulata. Macrospores from a four-day culture on potato extract agar at $20^{\circ} \mathrm{C} . \times 390$.

the sterigma (Fig. 12). This grouping, which is incidental for this species, is typical of E. viridescens, where chains are only occasionally seen. The disposition of conidia in groups may be easily overlooked when the conidia are mounted in liquid media, since they easily fall away from the sterigmata.

The colour exhibited in cultures of this species is due to the innumerable $\mathrm{D} d 2$ 
coloured conidia produced on the aerial mycelium. This colour is insoluble in ether, chloroform, alcohol, and water. When the spores are suspended in ether the liquid remains uncoloured; the spores sink slowly, indicating a lower specific gravity than in the case of $E$. viridescens. When suspended

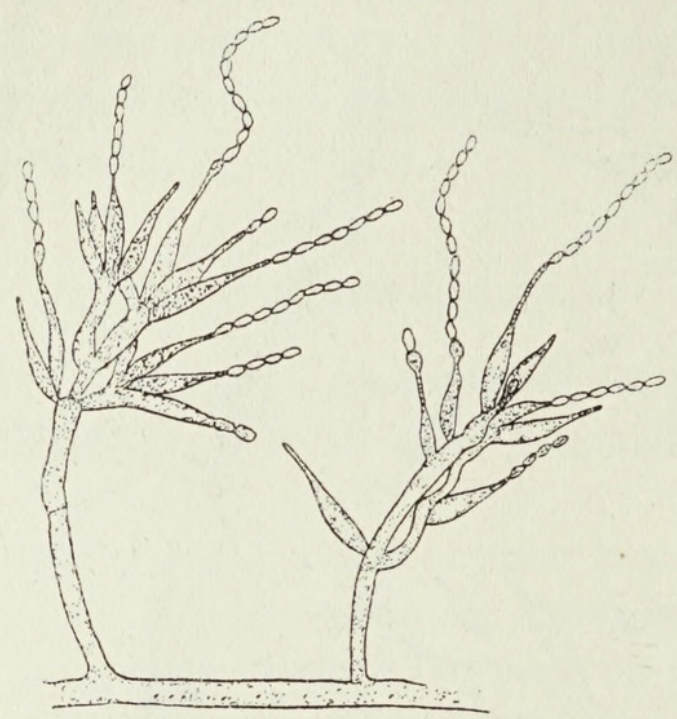

FIG. 9. E. catenulata. Condiophores. $\times 390$.

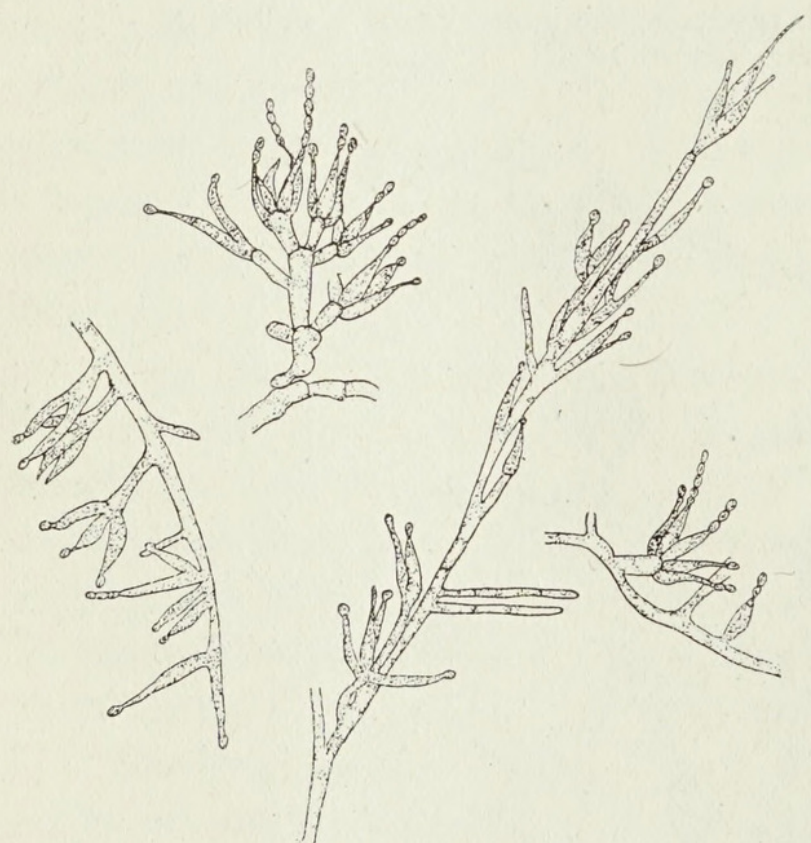

FIG. Io. E. catenulata. Conidiophores of various types on a synthetic medium plus agar at $20^{\circ} \mathrm{C}$. $\times 290$.
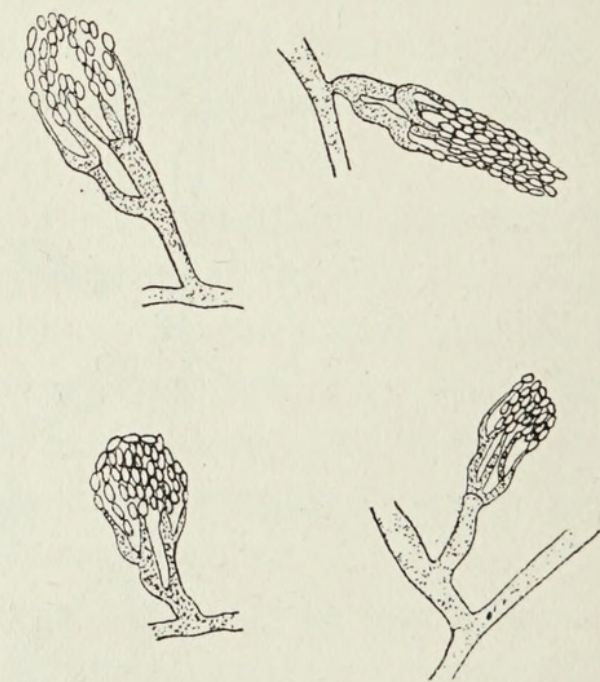

FIG. II. E. catenulata. The Penicillium type of conidiophore on potato glucose agar at $25^{\circ} \mathrm{C} . \quad \times 390$.

in chloroform the spores slowly rise to the surface, leaving the liquid uncoloured below.

The spore colour varies according to the medium (this factor had not so pronounced an effect as with E. viridescens), temperature, and the age of the growth. During fourteen days at $20^{\circ} \mathrm{C}$. (potato extract agar) the 
following sequence of colour changes was observed: pale cream, straw yellow, tawny olive to sayal brown; at $25^{\circ} \mathrm{C}$. on the same medium the sequence was straw yellow, old gold, and sayal brown specked with pinkish buff; while at $30^{\circ} \mathrm{C}$. the colours ranged from cream buff to honey yellow, and finally to avellaneous. Other colours produced on different media are Naples yellow, chamois, Isabella colour, russet, and cinnamon brown. The darker colours are those produced after about fourteen days' growth, and they do not show so much variation as in the case of $E$. viridescens.

The optimum temperature for growth proved to be $30^{\circ} \mathrm{C}$., moderate growth occurred at $25^{\circ} \mathrm{C}$., and least at $20^{\circ} \mathrm{C}$. Growth took place to

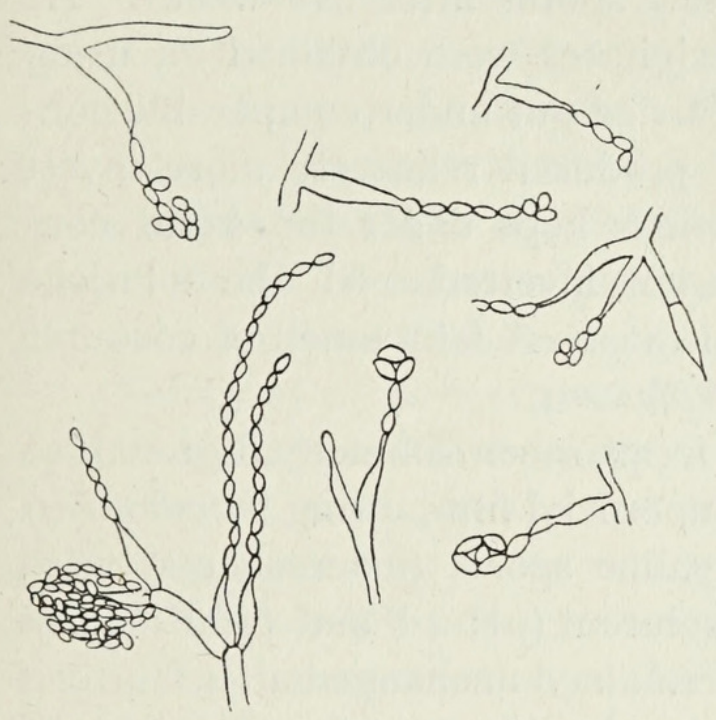

Fig. I2. E. catenulata. The formation of conidial group from a culture on potato extract agar at $25^{\circ} \mathrm{C} . \quad \times 39^{\circ}$.

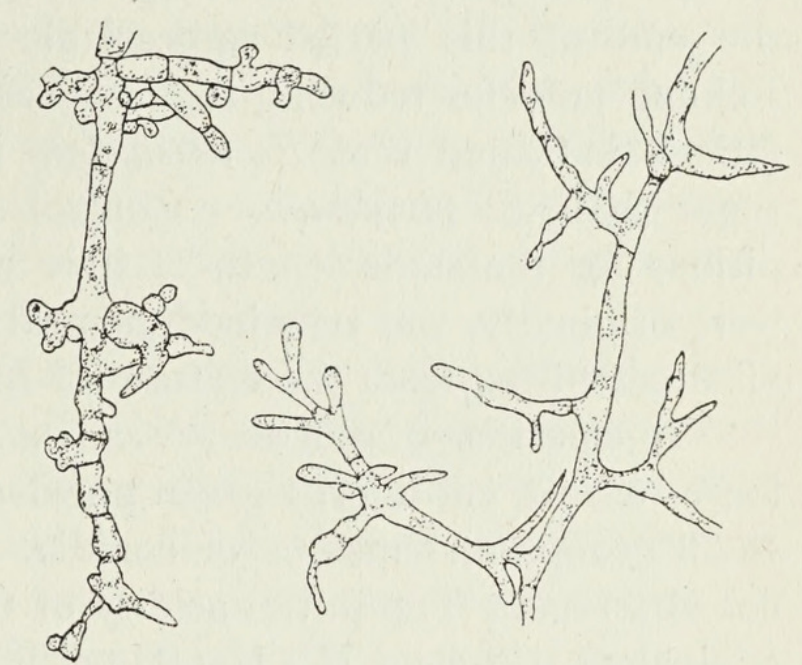

Fig. I3. E. catemulata. Mycelium with irregular swollen clusters of cells ; from a synthetic medium plus agar at $25^{\circ} \mathrm{C} . \quad \times 390$.

a greater or less extent on all the culture media employed except cellulose. On synthetic nutrient agar some variation occurred in the mycelium, where very irregular cells and small branches arose in clusters (Fig. I3) suggesting remotely the bulbils figured for E. acremonioides.

Bramley's seedling apples inoculated with $E$. catemulata after eight days at $20^{\circ} \mathrm{C}$. showed a surface growth of mycelium and conidiophores at the place of inoculation, but no parasitism of the living cell occurred.

Growth on seasoned pine, chestnut, beech, and oak was prolific, and penetration soon took place (in the case of E. viridescens no growth occurred).

\section{iil. Physiological Characters.}

A. Growth in Carbohydrate; Protein, and Asparagin.

$$
\text { I. Sugars. }
$$

Growth was studied in 4 per cent. solutions of sugars (flask cultures), sugar solutions with agar added (plate cultures), and nutrient agar containing sugar. 
The sugars used include glucose, sucrose, fructose, lactose, mannose, galactose, and maltose.

For the flask cultures the sugars were dissolved in distilled water, and steamed for thirty minutes on three consecutive days in the steam sterilizer. The flasks (capacity Ioo c.c. and containing 50 c.c.) were then inoculated, using small masses of spores in each case, and kept at a temperature of $20^{\circ} \mathrm{C}$. E. acremonioides produced only slight growth in maltose with a certain amount of sporing at the surface of the liquid, but no growth whatever occurred in glucose, sucrose, and lactose.

When grown in sucrose, both E. catenulata and E. viridescens produced feeble growth with comparatively few spores after five weeks. At the end of this period appreciable precipitates were obtained on using Fehling's test for reducing sugar. Tests carried out under comparable conditions indicated that $E$. catenulata had produced relatively more invert sugar than $E$. viridescens. Control solutions kept under the-same conditions for the same length of time were not inverted. All the solutions were originally, and remained, neutral to litmus. A faint smell of coco-nut oil was emitted from the cultures of E. viridescens.

In solutions of glucose E. catemulata forms much submerged growth of loose texture and a grey green powdery superficial film, owing its colour to small groups and masses of conidia. Hyaline spores (macrospores) were not observed. The initial acidity of the solution $(\mathrm{pH} 4.8$ and total acidity equivalent to I. 3 c.c. $\mathrm{N} / \mathrm{I} \mathrm{NaOH}$ per litre) remained unchanged after fourteen days' growth. E. viridescens also formed considerable growth and a powdery surface film, green owing to the colour of the spore masses. Intercalary and terminal hyaline spores were present. No change in the acidity occurred. The odour of coco-nut oil was moderately evident. The colour of the liquid initially pale yellow changed to bright yellow.

In lactose, E. catenulata formed much superficial and submerged growth after twenty days, accompanied by moderate spore formation. The acidity increased (initial acidity equivalent to 0.72 c.c. $\mathrm{N} / \mathrm{I} \mathrm{NaOH}$ per litre : final I c.c.). Under the same conditions E. viridescens also produced much growth with dark green superficial spore masses. The liquid initially uncoloured became bright yellow green, and a strong smell of coco-nut oil was emitted. The acidity increased (final acidity equivalent to I.2 c.c. $\mathrm{N} / \mathrm{I} \mathrm{NaOH}$ per litre). This result was not constantly obtained; in some cases the solution became less acid (initially $\mathrm{pH} 4.9$ : final, after thirty days, $\mathrm{pH} 5.6$ ), an anomaly probably due to differences in the degree of purity of the lactose used in different experiments.

Both E. catemulata and E. viridescens produce considerable growth in maltose (twenty days), the former species forming numerous spore masses, and the latter sporing moderately. The acidity in E. catenulata remained unchanged, but in $E$. viridescens it was slightly reduced (initial acidity 
equivalent to 2.96 c.c. $\mathrm{N} / \mathrm{1} \mathrm{NaOH}$ per litre : final 2.24 c.c.). The colour of the liquid (E. viridescens) changed from yellow to greenish yellow. Odour of coco-nut oil present.

$E$. viridescens produces moderate growth in galactose and little growth in mannose and fructose, when kept for eight weeks at $20^{\circ} \mathrm{C}$.; in each case the odour of coco-nut oil is obtained on heating the solution.

From these results, it is clear that the two fungi react differently in solutions of sugars : in $E$. viridescens growth is accompanied by coloration of the liquid and emission of odour; in E. catemulata these characteristics are absent.

Cultures of $E$. viridescens in maltose, glucose, lactose, and galactose were tested for actual utilization of sugar by titrating with Fehling's solution after thirty days' growth. The sugar in a control flask, kept under the same conditions, was estimated at the same time. Definite evidence that sugar had been utilized was obtained in each case: for example, with glucose control flasks contained 4 per cent. of sugar, the inoculated 3.5 per cent., lactose control 3.75 per cent., inoculated 3.5 per cent.

Solutions of pure sugar made up in conductivity water should prove neutral to litmus. The acidity of the solutions used in these experiments is attributed partly to the use of ordinary distilled water and partly to impurities present in the sugars themselves. Reduction of acidity where it occurs is probably not connected in any way with the fungal action on sugar, but due to reaction to the impurities present or to actual utilization of acid by the fungus.

The series of sugars containing agar comprised molar, and fifth, tenth, fiftieth, and hundredth molar solutions of lactose, glucose, and sucrose, using distilled water. The layer of medium in the plate when poured was approximately $3 \mathrm{~mm}$. thick. Two series of plates were prepared and inoculated with E. catemulata and E. viridescens respectively, and kept at $20 \cdot 5^{\circ} \mathrm{C}$. Control plates containing agar only were also prepared. Observations were made on the rate of growth in terms of the diameter of the colony, degree of sporulation, colour of the spore masses, and emission of odour.

The actual growth measurements made at twenty-four hours' intervals are given on p. 404.

The results do not differ in general from those obtained in liquid cultures. The odour of coco-nut oil was again evident in cultures of E. viridescens, whereas $E$. catenulata produced no smell. The growth-rate of $E$. viridescens is considerably greater than that of E. catemulata in molar solutions of all strengths, and the total growth at the end of four days is about three times as great. Since E. catenulata exhibits relatively slow growth as compared with $E$. viridescens under all temperature conditions, and even when cultures of these fungi are grown at their respective tempera- 
ture optima, the fact that $E$. catemulata was grown at a temperature below the optimum $\left(25^{\circ} \mathrm{C}\right.$.) would not greatly affect the comparative value of the results.

Growth in diameter (cm.) of E. viridescens in Solutions of Sugars.

Sugar. Strength.

$$
\begin{aligned}
& \text { Lactose }\left\{\begin{array}{l}
\mathrm{N} / 5 \\
\mathrm{~N} / 10 \\
\mathrm{~N} / 50 \\
\mathrm{~N} / 100
\end{array}\right. \\
& \text { Glucose }\left\{\begin{array}{l}
\mathrm{N} \\
\mathrm{N} / 5 \\
\mathrm{~N} / 10 \\
\mathrm{~N} / 50 \\
\mathrm{~N} / 100
\end{array}\right. \\
& \text { Sucrose }\left\{\begin{array}{l}
\mathrm{N} \\
\mathrm{N} / 5 \\
\mathrm{~N} / 10 \\
\mathrm{~N} / 50 \\
\mathrm{~N} / 100
\end{array}\right.
\end{aligned}
$$

\begin{tabular}{|c|c|c|c|}
\hline 24 & $4^{8}$ & $7^{2}$ & $9^{6}$ \\
\hline 0.8 & $2 \cdot 5$ & $5 \cdot 5$ & $7 \cdot 7$ \\
\hline 0.9 & 2.9 & $6.0^{\circ}$ & \\
\hline 0.9 & 2.85 & $5 \cdot 0$ & $7 \cdot 0$ \\
\hline$I \cdot I$ & $2 \cdot 75$ & $4 \cdot 7$ & $6 \cdot 5$ \\
\hline 0.4 & I. 6 & $3 \cdot 3$ & $4 \cdot 5$ \\
\hline 0.35 & $2 \cdot 5$ & $5 \cdot 0$ & $7 \cdot 2$ \\
\hline 0.8 & $3 \cdot 3$ & $5 \cdot 5$ & $7 \cdot 9$ \\
\hline 0.8 & 3.85 & $5 \cdot 2$ & $7 \cdot 3$ \\
\hline 0.85 & 2.9 & $4 \cdot 9$ & $7 \cdot 0$ \\
\hline 0.25 & $\mathrm{I} \cdot 3$ & 2.6 & $4^{\cdot 2}$ \\
\hline 0.8 & $3^{\cdot I}$ & $5 \cdot 7$ & $8 \cdot 4$ \\
\hline 0.2 & I. 9 & 4.9 & $7 \cdot 2$ \\
\hline 0.8 & $3 \cdot 0$ & $5 \cdot 3$ & $7 \cdot 3$ \\
\hline 0.8 & $2 \cdot 9$ & 4.9 & $7 \cdot 1$ \\
\hline 0.8 & 2.6 & $4 \cdot 6$ & $6 \cdot 6$ \\
\hline $0 . g$ & 2.65 & $4 \cdot 65$ & 6.55 \\
\hline
\end{tabular}

Control I.

Control II.

Growth in diameter $(\mathrm{cm}$.) of E. catenulata in Solutions of Sugars.

Sugar. Strength.

Lactose $\left\{\begin{array}{l}\mathrm{N} / 5 \\ \mathrm{~N} / 10 \\ \mathrm{~N} / 50 \\ \mathrm{~N} / 100\end{array}\right.$
Glucose $\left\{\begin{array}{l}\mathrm{N} \\ \mathrm{N} / 5 \\ \mathrm{~N} / 10 \\ \mathrm{~N} / 50 \\ \mathrm{~N} / 100\end{array}\right.$
Sucrose $\left\{\begin{array}{l}\mathrm{N} \\ \mathrm{N} / 5 \\ \mathrm{~N} / 10 \\ \mathrm{~N} / 50 \\ \mathrm{~N} / 100\end{array}\right.$

Control I.

\begin{tabular}{|c|c|c|c|}
\hline 24 & $4^{8}$ & $7^{2}$ & $9^{6}$ \\
\hline 0.15 & $0.6_{5}$ & 0.95 & 2.55 \\
\hline 0.25 & 0.7 & $1 \cdot 5$ & $2 \cdot 3$ \\
\hline 0.35 & 0.85 & $\mathrm{I} \cdot 35$ & $\mathrm{I} .8$ \\
\hline 0.35 & $0.8^{\circ}$ & $\mathrm{I} \cdot 2$ & $I \cdot 7$ \\
\hline $0 . \mathrm{I}$ & 0.7 & I. 6 & $2 \cdot 5$ \\
\hline 0.2 & 1.0 & 2.0 & 2.85 \\
\hline 0.4 & 0.9 & 1.8 & 2.8 \\
\hline 0.25 & 1.0 & $I \cdot 7$ & $2 \cdot 35$ \\
\hline 0.3 & 0.85 & 1.5 & $2 \cdot \mathrm{I}$ \\
\hline 0.15 & 0.9 & I. 65 & $2 \cdot 5$ \\
\hline 0.2 & $I \cdot I$ & $2.0^{\circ}$ & 2.9 \\
\hline 0.2 & $\mathrm{I} \cdot \mathrm{I}$ & I.95 & $2 \cdot 75$ \\
\hline 0.3 & 0.95 & 1.55 & 2.2 \\
\hline 0.3 & 0.8 & $\mathrm{I} \cdot 4$ & I. 9 \\
\hline 0.25 & 0.75 & I. 25 & I. 55 \\
\hline 0.2 & 0.7 & $\mathrm{I} \cdot \mathrm{I}_{5}$ & 1.5 \\
\hline
\end{tabular}

Control II.

\section{Interval in hours.}

The results are not strictly comparable with those obtained in the liquid cultures, since in this case agar is present, and both E.catemulata and $E$. viridescens are capable of growth and sporulation in agar alone, producing scanty mycelium and small scattered spore masses. Since agar itself belongs to the group of carbohydrate substances it is possibly utilizable to different degrees according to the kind of sugar added to it, and especially if impurities are present in it. Thus both E. catenulata and $E$. viridescens exhibited poor growth in sucrose as compared with lactose in liquid cultures, but in the plate cultures the growth after four days in sucrose and lactose is nearly the same. Little comparative value is attached to the growth differences exhibited in lactose, glucose, and sucrose respectively, since these 
results are likely to vary with the use of distilled water or conductivity water and according to the degree of purity of the chemicals themselves.

In both $E$. catemulata and $E$. viridescens the maximum growth occurs in $\mathrm{N} / 5$ or $\mathrm{N} / \mathrm{I} 0$ solutions. In the case of $E$. viridescens growth is considerably retarded in molar solutions, but in E. catemulata the retardation is not strongly marked.

In the case of $E$. viridescens, odour was present in every member of each series, being strongest in the fifth molar member. Whilst practically no difference could be detected between the glucose and lactose series the odour was appreciably less in the sucrose series. With regard to sporing, after four days no sporing was evident in the unimolar cultures: in the remaining cultures very little difference in the amount of sporing was manifest. The sporing is confined to a zone about $\mathrm{I}_{5}$ to $\mathrm{I} 7 \mathrm{~mm}$. wide in the peripheral region of the colony. After a longer period of time the colour of the spore masses in unimolar glucose varied from white to pale olivine, passing to dark yellowish green and dark green in $\mathrm{N} / 50$ and bottle-green in $\mathrm{N} / \mathrm{I} 00$, with the central region of the plate free from spores: in lactose the colour varied from pale olivine to French green in $\mathrm{N} / 5$ and $\mathrm{N} / 10$, changing to Empire green in $\mathrm{N} / \mathrm{ro0}$, whilst in sucrose the colour ranged from French green to Danube green.

In the case of $E$. catemulata there was little colour variation in the spore masses (relatively more numerous in $\mathrm{N} / 5$ cultures) throughout the series; the colour varied from cream-buff to chamois, whereas in agar alone it was avellaneous.

\section{Starch.}

The ability of the species of Eidamia to hydrolyse starch was tested by the method employed by George L. Peltier (14). Peltier applied a solution of iodine in potassium iodide to the surface of starch-containing media containing growths of Pseudomonas citri, and found that the colonies of P. citri remained yellow, whilst the surrounding medium was coloured dark blue. Each colony was surrounded by a narrow, clear, starch-depleted zone: this was followed by a reddish-brown band indicating erythrodextrin, an intermediate product, which merged into a bright blue band and finally into the dark blue colour of the starch-containing agar. This method has been in use for some time by the first-named writer as an aid to the specific determination of fungi, since fungi often show well-marked differences in the effect produced upon irrigation with iodine, related chiefly to the width of the coloured and uncoloured zones and the intensity of the colours present in the region where partial hydrolysis exists. Various starch-containing media were used for this purpose, notably potato extract agar with or without various organic acids and synthetic nutrient media of different kinds. In the case of Eidamia acremonioides no evidence indicating starch hydrolysis 
was obtained. In E. catemulata (potato extract agar with a 0.25 per cent. concentration of malic acid) after six days at $20^{\circ} \mathrm{C}$. the colony, after irrigation, was surrounded by a narrow clear zone with a purplish-pink border where it abutted on the starch-containing agar: the altered zone having a width of from 2 to $3 \mathrm{~mm}$. The agar below the colony was uncoloured. A certain amount of variation occurred in plates containing other concentrations of malic acid : thus with a I per cent. concentration the purplish band coincided with the margin of the colony. Very similar results were obtained with E. viridescens.

Owing to the very poor growth of E. acremonioides obtained in the plate cultures, the failure to obtain a definite reaction by iodine irrigation could not be ascribed to the inability of the species to hydrolyse starch. Hence it was necessary to employ other methods. Solutions containing I per cent. peptone and O.I per cent. starch made up in flasks were inoculated with the three fungi and kept at $20^{\circ} \mathrm{C}$. for five and a half days. Each fungus having produced a moderate amount of growth in this period, the peptone-starch solutions were tested with a weak iodine solution. With a given amount of iodine added to a fixed quantity of peptone-starch, the control (uninoculated solution) was deeply coloured; the solution containing $E$. acremonioides exhibited the same intensity of coloration as the control; the solution with $E$. catenulata was slightly coloured, whilst that containing E. viridescens was uncoloured. Again, E. acremonioides did not show any indication of action upon starch. A difference in the amount of hydrolysis, induced through the growth activities of E. catenulata and E. viridescens respectively, was apparent.

A further experiment was made using I per cent. wheaten starch made up with distilled water. The flasks were kept at $20^{\circ} \mathrm{C}$. and tested after three weeks. At the end of this period E. acremonioides had made practically no growth. The solutions containing the remaining species were tested with standard iodine solution as before. In E. viridescens hydrolysis was nearly complete: the liquid was of a greenish colour and a pronounced smell of coco-nut oil was evident. In E. catenulata hydrolysis was incomplete. No acid was produced in either case.

Since $E$. viridescens is a more rapidly growing fungus than E.catemulata, its greater hydrolysing activity, under the conditions obtaining in these experiments, is not surprising.

\section{Soluble Pectin.}

The ability of the species of Eidamia to grow in soluble pectin extracted from apples was tested in connexion with a series of experiments, relating to fungal growth in pectin, carried out by the first-named author in collaboration with Miss M. H. Carré (2). Since these experiments will be 
described in detail elsewhere it is unnecessary to make more than brief reference to this subject here. The growth experiments were carried out in 50 c.c. flasks containing 25 c.c. of a I per cent. neutral solution of practically pure pectin. The amount of pectin actually present in each flask was estimated after autoclaving. The flasks were inoculated in duplicate series and kept at $20^{\circ} \mathrm{C}$. for a given period. At the end of this period final pectin estimations were made, the solutions were titrated against standard alkali and tested with Fehling's solution for the presence of reducing sugar. The following general results were obtained:

E. acremonioides. No growth.

E. catemulata. Moderate growth with utilization of pectin. Solution slightly acid. Liquid does not become green. Fehling's solution not reduced.

E. viridescens. Moderate growth. Pectin completely used up. Solution slightly acid. Liquid becomes greenish in colour. Fehling's solution reduced.

\section{Peptone.}

Flasks, containing a 2 per cent. solution of peptone with an initial $\mathrm{pH} 6.8$ and total acidity equivalent to Io c.c. $\mathrm{N} / \mathrm{r} \mathrm{NaOH}$ per litre, were inoculated with $E$. catemulata, E. viridescens, and $E$. acremonioides and kept at a temperature of $20^{\circ} \mathrm{C}$. After fourteen days the growth characteristics were recorded, the final $\mathrm{pH}$ was obtained by the indicator method, the totalalkalinity estimated in terms of c.c. $\mathrm{N} / 1 \mathrm{HCl}$ using neutral red asindicator, and the atmosphere of the flask tested for the presence of ammonia by means of suspended litmus paper.

Result:

E. catemulata. Moderate floating and submerged growth: superficial growth with a fine, white, mealy appearance: both conidia and macrospores present. Solution alkaline to litmus and suspended red litmus paper blues slowly. $\mathrm{pH} 7 \cdot 8$. Alkalinity equivalent to $5 \cdot 8$ c.c. $\mathrm{N} / \mathrm{s} \mathrm{HCl}$ per litre.

E. viridescens. Moderate submerged and somewhat gelatinous growth, suspended from large white colony occupying the whole surface of the liquid, depressed in the middle with wrinkled margin: conidia not observed: macrospores present, but relatively small. Ammonia present : red litmus blues rapidly. Solution alkaline. $\mathrm{pH} 8 \cdot \mathrm{I}$. Alkalinity 6 c.c. N/I $\mathrm{HCl}$ per litre.

E. acremonioides. Somewhat meagre submerged growth of loose texture: mycelium white with terminal and intercalary swollen cells : macrospores rare; ends of branches resemble appressoria, probably incipient conidiophore formation. Ammonia not detected. Solution neutral to litmus. $\mathrm{pH} 6 \cdot 9$. Acidity equivalent to 12 c.c. N/I NaOH per litre. 


\section{Peptone and Glucose.}

Flasks (capacity 50 c.c.), containing 25 c.c. each of a solution made up to contain 2 per cent. peptone and 4 per cent. glucose, with an initial $\mathrm{pH} 5 \cdot 0$ and total acidity equivalent to 34 c.c. $\mathrm{N} / \mathrm{I} \mathrm{NaOH}$ per litre, were inoculated with the three species and kept at $20^{\circ} \mathrm{C}$. Observations were made as in the case of peptone after fourteen days' growth.

Result:

E. catenulata. Considerable thick growth of a somewhat leathery consistency and very much wrinkled: colour white to grey and buff: both macrospores and conidia present, but the latter not numerous. Ammonia not detected. Solution acid to litmus; strong yeasty smell emitted. $\mathrm{pH} 4 \cdot 2$. Total acidity equivalent to 56 c.c. $\mathrm{N} / \mathrm{s} \mathrm{NaOH}$ per litre.

$E$. viridescens. Growth similar in character to that exhibited by $E$. catenulata, but less bulky. Surface growth cream-grey. Macrospores numerous: conidia not observed. Ammonia present, but litmus blues slowly. Solution acid to litmus. Strong odour of coco-nut oil emitted. pH $4 \cdot 6$. Total acidity equivalent to 40 c.c. $\mathrm{N} / 1 \mathrm{NaOH}$ per litre.

$E$. acremonioides. Much submerged growth: surface growth meagre, thin, greyish white in colour: mycelium white, tough: incipient hyaline macrospores present; conidia not observed. Ammonia not detected. Solution acid to litmus. $\mathrm{pH}$ 5.1. Total acidity equivalent to 30 c.c. $\mathrm{N} / \mathrm{I} \mathrm{NaOH}$ per litre.

\section{Asparagin.}

With E. catenulata, E. viridescens, and $E$. acremonioides very little growth occurred in I per cent. asparagin made up in distilled water. The growth was comparable to that in distilled water without asparagin. The growth obtained when $E$. catemulata and $E$. viridescens were grown in solutions containing I per cent. asparagin and 4 per cent. glucose was comparable to that obtained when these species are grown in 4 per cent. glucose without asparagin. When, however, mineral salts are present in addition to glucose and asparagin, the reactions occurring are similar to those obtained when these fungi are grown in peptone alone, viz. the solution becomes alkaline and ammonia is liberated.

\section{B. Growth Limitation in Relation to Hydrogen-ion Concentration.}

For the investigation of growth limitation on the acid side, N/IO, N/I00, and $\mathrm{N} / \mathrm{I} 000$ solutions of $\mathrm{HCl}$ made up with distilled water, and solutions of neutralized potato extract and potato extract agar, to which the acids were added in similar concentrations, were used. The $\mathrm{pH}$ values of all the media thus prepared were determined, after autoclaving, by the electrical method. By this means a series of media having a wide hydrogen-ion concentration range was obtained. For these experiments the two species, 
E. catemulata and E. viridescens, were employed. The solutions of $\mathrm{HCl}$ and $\mathrm{HCl}$ potato extract were made up in $25^{\circ}$ c.c. flasks containing each 100 c.c. of liquid. The $\mathrm{HCl}$ potato extract agar was used for plate cultures, and growth measurements in terms of the diameter of the colony were made at regular intervals. The more important results are given in tabular form below :

\section{Growth in media containing $\mathrm{HCl}$ of different initial hydrogen- ion concentrations at $20^{\circ} \mathrm{C}$.}

\begin{tabular}{|c|c|c|c|c|}
\hline \multicolumn{2}{|c|}{ Medium. } & $p H$. & E. catenulata. & E. viridescens. \\
\hline$\frac{\mathrm{N}}{\mathrm{IO}}$ & $\mathrm{HCl}$ sol. & 1.03 & nil & nil \\
\hline$\frac{N}{10}$ & HCl P.E. sol. & I.I 6 & several small colonies & nil \\
\hline$\frac{\mathrm{N}}{\mathrm{IO}}$ & $\mathrm{HCl}$ P.E. agar & I. 23 & colony $5 \mathrm{~mm}$. & nil \\
\hline$\frac{N}{100}$ & $\mathrm{HCl}$ sol. & $2 \cdot 0$ & $\begin{array}{l}\text { numerous colonies } \\
\text { (I } 4 \text { days) }\end{array}$ & $\begin{array}{l}\text { very slight growth } \\
\text { (3 days) } \\
\text { numerous colonies } \\
\text { (I } 4 \text { days) }\end{array}$ \\
\hline$\frac{\mathrm{N}}{1000}$ & $\mathrm{HCl}$ sol. & $3 \cdot 0$ & $\begin{array}{l}\text { numerous colonies } \\
\text { (I } 4 \text { days })\end{array}$ & some growth \\
\hline$\frac{N}{100}$ & HCl P.E. agar & $4 \cdot I 5$ & colony $\mathrm{I} .5 \mathrm{~cm}$ & colony $6.2 \mathrm{~cm}$. \\
\hline$\overline{100}$ & HCl P.E. sol. & $4 \cdot 35$ & $\begin{array}{l}\text { much growth, } \\
\text { larger colonies }\end{array}$ & much growth \\
\hline Disti & ed water & $5 \cdot 8$ & nil & nil \\
\hline$\frac{N}{1000}$ & HCl P.E. agar & $6 \cdot 4$ & colony $0.8_{5} \mathrm{~cm}$. & colony $3 \mathrm{~cm}$. \\
\hline$\frac{\mathrm{N}}{1000}$ & HCl P.E. sol. & $7 \cdot 88$ & $\begin{array}{l}\text { one colony } \\
\text { ( similar to P.E. } \\
\text { control) }\end{array}$ & much growth \\
\hline
\end{tabular}

N.B. The data given are those after 3 days' growth unless stated otherwise.

The following points are evident:

I. The limit for E. catenulata (in $\mathrm{N} / \mathrm{I}$ o $\mathrm{HCl} \mathrm{P.E.} \mathrm{solution)} \mathrm{is} \mathrm{pH} \mathrm{I} \cdot \mathrm{I} 6$ approximately.

2. The limit for $E$. viridescens (in $\mathrm{N} / \mathrm{I} 00 \mathrm{HCl}$ ) is approximately $\mathrm{pH} 2$. It will be noted that growth diminishes as the neutral point is approached with both species ( see growth in solutions initially $\mathrm{pH} 4 . \mathrm{I} 5$ and $\mathrm{pH} 6 \cdot 4$ respectively).

In the case of $E$. acremonioides no growth was obtained in nutrient media containing more than one per cent. concentration of malic or tartaric acid : the hydrogen-ion concentration of these media would be less than that indicated by $\mathrm{pH} 3$.

In order to obtain growth limits on the alkaline"side a boric acid buffer solution was employed. The solutions used were prepared as follows :

A. Buffer solution only, in flasks.

(a) 5 o c.c. $\mathrm{H}_{3} \mathrm{BO}_{3}, \mathrm{KCl}\left(12 \cdot 4048\right.$ grm. $\mathrm{H}_{3} \mathrm{BO}_{3}+\mathrm{I} 4.9 \mathrm{I} 2 \mathrm{grm}$. $\mathrm{KCl}$ to 
I,000 c.c. distilled water) + IO c.c. $\mathrm{N} / 5 \mathrm{NaOH}$ diluted to 200 c.c. with distilled water. $\mathrm{pH} 8 \cdot 7$.

(b) 50 c.c. $\mathrm{H}_{3} \mathrm{BO}_{3}, \mathrm{KCl}+25$ c.c. $\mathrm{N} / 5 \mathrm{NaOH}$ diluted to 200 c.c. $\mathrm{pH} 9 \cdot 3$.

(c) 50 c.c. $\mathrm{H}_{3} \mathrm{BO}_{3}, \mathrm{KCl}+45$ c.c. $\mathrm{N} / 5 \mathrm{NaOH}$ diluted to 200 c.c. $\mathrm{pH}$ Iо.

(d) Distilled water.

B. A similar series in which the dilutions were made with neutralized potato extract instead of distilled water.

(a) $\mathrm{pH} 8 \cdot 5:$ (b) $\mathrm{pH} 8.9:$ (c) $\mathrm{pH} 9 \cdot 8:$ (d) neutralized potato extract, $\mathrm{pH} 8$.

C. A similar series in which the dilutions were made with neutralized potato extract agar (1.5 per cent.).

(a) $\mathrm{pH} 8$ to $8 \cdot 2:($ b) $\mathrm{pH} 8 \cdot 5:$ (c) $\mathrm{pH} 9 \cdot \mathrm{I}:(d)$ neutralized potato extract agar, pH 6 approximately.

The $\mathrm{pH}$ values were obtained by the indicator method after the media had been autoclaved. Owing to the fact that the agar is coloured to a certain extent, the exact value was difficult to obtain in media containing agar.

The media were made up in flasks containing 50 c.c. each, autoclaved, subsequently inoculated, using the three species of Eidamia, and kept at $20^{\circ} \mathrm{C}$. The results obtained are given below :

Growth at $20^{\circ} \mathrm{C}$. in boric acid buffer solutions and media containing boric acid buffer solutions, of different hydrogen-ion concentrations.

Medium.

P.E. agar (C.d.)

P.E. (B. d.)

P.E. agar with

buffer (C. a.)

Various

pH.
6
8
$8-8 \cdot 2$
$8.5^{-10}$

E. viridescens.
moderate
solid gela-
tinous mass
slight
nil

E. acremonioides. moderate scum-like growth nil nil

N.B. At the end of $I_{5}$ days the hydrogen-ion concentration of the liquid in neutralized potato

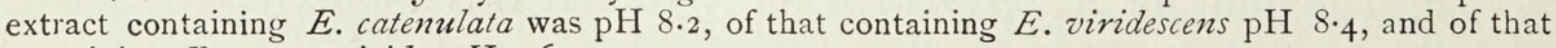
containing $E$. acremonioides $\mathrm{pH} 7.6$.

Additional experiments were made with $E$. catenulata and E. viridescens using buffer solutions grading from $\mathrm{pH} 6 \cdot 4$ to $7 \cdot 6$, hydrogen-ion concentrations at which moderate growth occurs in other media (not containing boric acid), but the growth produced was of a feeble character in each case. A species of Aposphaeria, on the other hand, formed numerous well-defined colonies in boric acid buffer solutions, containing no other source of nutrient, ranging from $\mathrm{pH} 7.8$ to $\mathrm{pH}$ IO, and Pleospora pomorum was capable of growth at $\mathrm{pH} 8 \cdot 7$. From these results it seems probable that the boric acid exerts an unfavourable effect on growth in so far as the species of Eidamia 
are concerned, and hence the respective limits obtained for the species, viz. $E$. catemulata and $E$. viridescens, $\mathrm{pH} 8.2$, and $E$. acremoniodes, $\mathrm{pH}$ 8, should be regarded as very approximate.

\section{Utilization of Acid.}

Since it was found that both E. catemulata and E. viridescens were capable of growth in solutions of acids made up in distilled water, in the absence of other source of nutrient, several experiments were made by titration with standard alkali, with a view to ascertaining whether the acid was actually utilized. For the purpose of the experiments flasks containing 50 c.c. of 1 per cent. solution of acid in distilled water were prepared. The flasks were set up in duplicate series and inoculated with $E$. catemulata and $E$. viridescens respectively. Control flasks were prepared, and flasks inoculated with Penicillium glaucum set up for comparison. In a particular experiment tartaric $\left(\mathrm{pH} \mathrm{I}^{\circ} 9\right)$, malic $\left(\mathrm{pH}_{2} \cdot 2\right)$, and citric $\left(\mathrm{pH}_{2} \cdot \mathrm{I}\right)$ acids were used. The cultures were kept at $25^{\circ} \mathrm{C}$. for three months. At the end of this period the original volume of the liquid in the flasks had been somewhat reduced owing to evaporation; accordingly in the case of each acid the volume in the inoculated flasks was made up to those of its iespective control, using conductivity water (neutral). The results are given Delow in terms of c.c. $\mathrm{N} / \overline{5} \mathrm{NaOH}$ required to neutralize Io c.c. of acid solution.

\section{Amount of growth and acid utilized in I per cent. solutions of certain organic acids.}

\begin{tabular}{l}
\multicolumn{1}{c}{ Acid. } \\
Tartaric control \\
E. catemulata \\
E. viridescens \\
P. glaucum \\
Malic control \\
E. catemulata \\
E. viridescens \\
P. glaucum \\
Citric control \\
E. catenulata \\
E. viridescens \\
P. glaucum
\end{tabular}

c.c. $\mathrm{N} / 5 \mathrm{NaOH}$

8.15
$7 \cdot 7$
7.5
$8 \cdot 1$
8.975
7.95
8.05
8.0
8.65
7.95
8.3
8.6

Growth.
poor
poor
nil
moderate
moderate
moderate
poor
poor
nil

The amount of growth corresponded fairly closely to the quantity of acid used in each case.

$P$. glaucum differed from the species of Eidamia in producing no growth in I per cent. tartaric and citric acids. It was at first thought that the action upon acid might be due to an avidity for one or other of the stereoisomeric modifications of the organic acids employed. Accordingly, flasks, containing 2 per cent. racemic acid obtained from Kahlbaum made up with distilled water, were inoculated with Eidamia catemulata and E. viridescens respectively. The flasks were kept at $20^{\circ} \mathrm{C}$. for one month. The solutions were then tested in the polarimeter, but there was no deviation from zero in 
each case. Since the specific rotation of tartaric is 15.06 , the rotation for a 2 per cent. solution would be only 0.30 approximately-

$$
\left(\text { specific rotation }=\frac{\text { rotation per decimetre length }}{\text { conc. in grm. per I c.c. }}\right) \text {; }
$$

therefore when small amounts of acid are utilized it would be difficult to obtain a polarimeter reading which would fall outside the limits of probable error. For this reason this method was abandoned. It was also found impractical to work with synthetic nutrient media, such as Coon's, with racemic acid added, since the angle of rotation is often greatly affected by the presence of the optically active carbohydrate or protein which these media contain. Pasteur (13) found that when some pure ammonium racemate is dissolved in water containing a small quantity of phosphates and inoculated with Penicillium glaucum this fungus is able to grow and sporulate: correlated with this growth the dextrorotatory modification of racemic acid disappears, leaving only levorotatory acid. Accordingly some ammonium racemate was prepared by taking Ioo c.c. of 5 per cent. racemic acid and adding to it $18 \cdot 4$ c.c. of ammonia of strength $0.22 \mathrm{~N}$. This amount of ammonia should neutralize the racemic acid. To this solution $0.148 \mathrm{grm}$. $\mathrm{K}_{3} \mathrm{PO}_{4}$ were added. This medium was then autoclaved, and flasks, containing 25 c.c. of solution each, were inoculated with Eidamia catemulata, E. viridescens, and Penicillium glaucum. The usual controls were set up. At the end of three months $P$. glaucum had produced numerous colonies, but no growth had taken place in the flasks containing $E$. catenulata and $E$. viridescens. This result was the opposite to that obtained when the fungi were grown in tartaric acid without other source of nutrient. Hence, from the evidence, neither $E$. catemulata nor E. viridescens appears to resemble Penicillium glaucum in its behaviour towards organic acids exhibiting stereo-isomerism. Where growth in these acids occurs it seems probably due to a reaction analogous to certain bacterial acid fermentations, such as the fermentation of malic acid by $B$. lactis aerogenes and citric acid by $B$. cloacae.

\section{Growth on Agar with Organic Acid in Various Concentrations.}

The general method adopted for these experiments was to prepare a number of flasks, containing a known quantity each of neutralized agar solution made up with distilled water, and an equal number of test-tubes, containing small measured quantities of acid of different known concentrations, devised with a view to obtaining, upon adding the acid to the agar, a series of media containing definite percentage concentrations of each acid.

The flasks and tubes were autoclaved and the acids rapidly added to the flasks after autoclaving and before the agar had commenced to solidify.

In the case of malic, citric, and tartaric acids, I, $0.5,0.25,0.1$, and 0.05 
percentage concentrations were employed. Experiments were made on several occasions using different batches of similarly prepared media, and the cultures were kept at various temperatures, approximately constant for each experiment. In a particular experiment ( $6.5^{\circ}$ to $\mathrm{I} 8 \cdot 2^{\circ} \mathrm{C}$.) using E. catemulata the total growth at the end of ten days was as follows :

\section{Growth in diameter $(\mathrm{cm}$.) of E. catenulata on agar containing organic acid in different concentrations.}

\begin{tabular}{|c|c|c|c|c|c|c|}
\hline Acid. & $I \cdot O$ & 0.5 & 0.25 & 0.1 & $0.05 \%$ & Control. \\
\hline Malic & $3 \cdot 9$ & $4 \cdot I$ & $4 \cdot 0$ & $4 \cdot 4$ & $4 \cdot 2$ & \\
\hline Citric & $4 \cdot 1$ & 4.0 & 3.9 & $3 \cdot 9$ & $4 \cdot 2$ & $2 \cdot 3$ \\
\hline Tartaric & $4 \cdot I$ & $4 \cdot 0$ & $3 \cdot 9$ & $4 \cdot 2$ & $3 \cdot 9$ & \\
\hline
\end{tabular}

At these relatively low acid concentrations the rate of growth is very similar throughout a given series, and in each case there is more growth than in the control plates. Although the rate of growth in tartaric is nearly equal to that in malic and citric acids, the fungus forms growth of a more meagre character and produces fewer spore masses, hence it is not surprising that the amount of tartaric acid utilized by the fungus after a long period (see section relating to utilization of acid) is less than that of malic or citric acid. Somewhat similar results were obtained for E. viridescens, but in the case of $E$. acremonioides no growth was obtained in the malic, citric, and tannic acid series, with the exception of 0.05 per cent. citric, where growth was of a very meagre character.

\section{Growth in diameter $(\mathrm{cm}$.) of E. catemulata on agar containing.} tannic acid in different concentrations.

Concentration.

2.0
$1 \cdot 5$
1.0
0.5
0.25
0.1
C. 1
C. 2

Interval in days.

\begin{tabular}{|c|c|c|c|c|c|}
\hline 4 & 5 & 6 & 7 & 9 & IO \\
\hline 0.35 & $\overline{0.7}$ & $\overline{1.05}$ & $\overline{\mathrm{I}} \cdot 35$ & $\overline{2 \cdot 0}$ & $\begin{array}{l}2.5 \times I \\
2.2\end{array}$ \\
\hline 0.6 & 0.95 & I. 4 & 1.8 & 2.8 & $3 \cdot 2$ \\
\hline 0.65 & $\mathrm{I} \cdot \mathrm{I}$ & I. 6 & 2.0 & 3.0 & $3 \cdot 45$ \\
\hline 0.7 & $\mathrm{I} \cdot 2$ & $\mathrm{I} \cdot 7$ & $2 \cdot I$ & $3 \cdot I_{5}$ & 3.55 \\
\hline 0.8 & $I \cdot 3$ & $1 \cdot 7$ & $2 \cdot 25$ & $3 \cdot 3$ & 3.8 \\
\hline 0.55 & 1.05 & $\mathrm{I} \cdot 45$ & I.9 & $2 \cdot 55$ & 3.05 \\
\hline & $\mathrm{I} \cdot \mathrm{I}$ & $1 \cdot 4$ & & $2 \cdot 5$ & 2.95 \\
\hline
\end{tabular}

At the end of ten days, growth in all concentrations except 1.5 and 2. is greater than that in the controls.

Growth was considerably checked in the 2 per cent. series; slight growth of an irregular character was observed on the seventh day.

The growth-rate increased very slightly, passing from the 1.5 to 0 . I concentrations although the hydrogen-ion concentration exhibits little change ( 2 per cent. $=\mathrm{pH}_{4} \cdot 4$; I per cent. $=\mathrm{pH}_{4} \cdot 4$ ). 
Growth in diameter $(\mathrm{cm}$.) of $E$. viridescens on agar containing tannic acid in different concentrations.

Concentrations.

$2.0-0.5$
0.25
$O .1$
C. 1
C. 2

\begin{tabular}{ll}
\multicolumn{1}{c}{4} & \multicolumn{1}{c}{5} \\
nil & nil \\
0.35 & 0.35 \\
0.25 & 0.5 \\
2.05 & $4 \cdot 2$ \\
$2 \cdot \mathrm{I}$ & 4.35
\end{tabular}

Interval in days.

Growth occurred only in cultures containing 0.25 and $0 . \mathrm{I}$ per cent. acid with appreciable growth only in the I per cent. concentration, but considerably less than that in the control plates.

From observations made of growth in other media with a similar $\mathrm{pH}$ value, the hydrogen-ion factor should not cause growth retardation to this extent. Hence the check to growth must be ascribed to some other factor.

Growth in diameter (cm.) of E. catenulata and E. viridescens on agar containing gallic acid in different concentrations.

Concentrations. Interval in days.'

\begin{tabular}{|c|c|c|c|c|c|c|}
\hline & 4 & 5 & 6 & 7 & 9 & IO \\
\hline \multicolumn{7}{|c|}{ I. E. catenulata. } \\
\hline $2 \cdot 0$ & $c .2$ & 0.5 & 0.8 & $\mathrm{I} .05$ & I. 6 & $\mathrm{I} \cdot 95$ \\
\hline $\mathrm{I} \cdot 5$ & 0.5 & 0.9 & $1 \cdot 2$ & $1 \cdot 6$ & $2 \cdot 4$ & $2 \cdot 9$ \\
\hline I. 0 & 0.65 & $I \cdot 3$ & $I \cdot 7$ & $2 \cdot 2$ & $3 \cdot 3$ & $3 \cdot 8$ \\
\hline 0.5 & 0.8 & $I \cdot 45$ & 2.0 & $2 \cdot 6$ & $3 \cdot 9$ & $4 \cdot 55$ \\
\hline 0.25 & $0.8_{5}$ & $\mathrm{I} \cdot 55$ & $2 \cdot 2$ & $2 \cdot 7$ & $4 \cdot 0$ & $4 \cdot 65$ \\
\hline 0.1 & 0.8 & $\mathrm{I} \cdot 55$ & $I \cdot 95$ & $2 \cdot 7$ & $3 \cdot 85$ & $4 \cdot 5$ \\
\hline C. I & 0.55 & $\mathrm{I} \cdot \mathrm{O}_{5}$ & $I \cdot 45$ & $I \cdot 9$ & $2 \cdot 55$ & 3.05 \\
\hline C. 2 & 0.6 & $I \cdot I$ & $I \cdot 4$ & $\mathrm{I} \cdot 8$ & $2 \cdot 5$ & $2 \cdot 95$ \\
\hline \multicolumn{7}{|c|}{ II. E. viridescens. } \\
\hline $2 \cdot 0-1.0$ & nil & nil & nil & nil & nil & nil \\
\hline 0.5 & 0.6 & $0.9 \times I .1$ & $\mathrm{I} \cdot 4 \times \mathrm{I} \cdot 7$ & $2.8 \times 3.0$ & $5.9 \times 6.0$ & $7.0 \times 7.5$ \\
\hline 0.25 & $I \cdot 2$ & $2.7 \times 2.9$ & $4 \cdot 6 \times 4 \cdot 7$ & $6 \cdot 3 \times 6 \cdot 7$ & $>10.0$ & $>10.0$ \\
\hline 0.1 & $\mathrm{I} \cdot 7$ & $3 \cdot 6$ & $5 \cdot 6$ & $7 \cdot 3 \times 7.5$ & $>10.0$ & $>10.0$ \\
\hline C. I & 2.05 & $4 \cdot 2$ & $5 \cdot 85$ & $7 \cdot 65$ & 10.6 & $>1 I \cdot 0$ \\
\hline C. 2 & $2 \cdot \mathrm{I}$ & $4 \cdot 35$ & 6.15 & 8.1 & 10.5 & $>\mathrm{II} \cdot 0$ \\
\hline
\end{tabular}

N.B. The $\mathrm{pH}$ values of the gallic agars were as follows : $2 \%=\mathrm{pH} 3 . \mathrm{I} ; \mathrm{I} \%=\mathrm{pH} 3.2$; $0.1 \%=\mathrm{pH} 3.8$.

The following are the chief points of interest:

I. E. catenulata.

(a) The total growth at the end of ten days exceeds that in the controls (agar alone) in all except the 2 and $I .5$ per cent. members of the series.

(b) Increase in the rate of growth occurs when passing from the 2 to 0.5 per cent. concentration.

II. E. viridescens.

(a) No growth occurred in $2, \mathrm{I} \cdot 5$, and I per cent. gallic agars. 
(b) The total growth in any case does not exceed that in the controls.

(c) Increase in the growth-rate occurs, passing from the 0.5 to $0 . \mathrm{I}$ per cent. concentrations.

In both species growth in each member of the series is greater than that in the corresponding members of the tannic agar series, although from the point of view of the hydrogen-ion factor (taking into consideration the data obtained when other media with a similar $\mathrm{pH}$ range are used) the reverse result might be anticipated.

It is worthy of note that practically no acceleration of growth occurs in any given member of the tannic and gallic acid series. This is probably due to the fact that there is no appreciable production of ammonia (compounds of nitrogen would not exist except as impurities), hence change in the hydrogen-ion concentration through acid neutralization would not occur.

\section{E. Growth on Potato Extract Agar with Organic Acid in Various Concentrations.}

Numerous experiments were made with acid agars, using neutralized potato extract, employing methods of preparing the media and obtaining growth statistics similar to those already described (section II). Since the acid agar experiments have been described in some detail, the chief results are expressed in graph form:

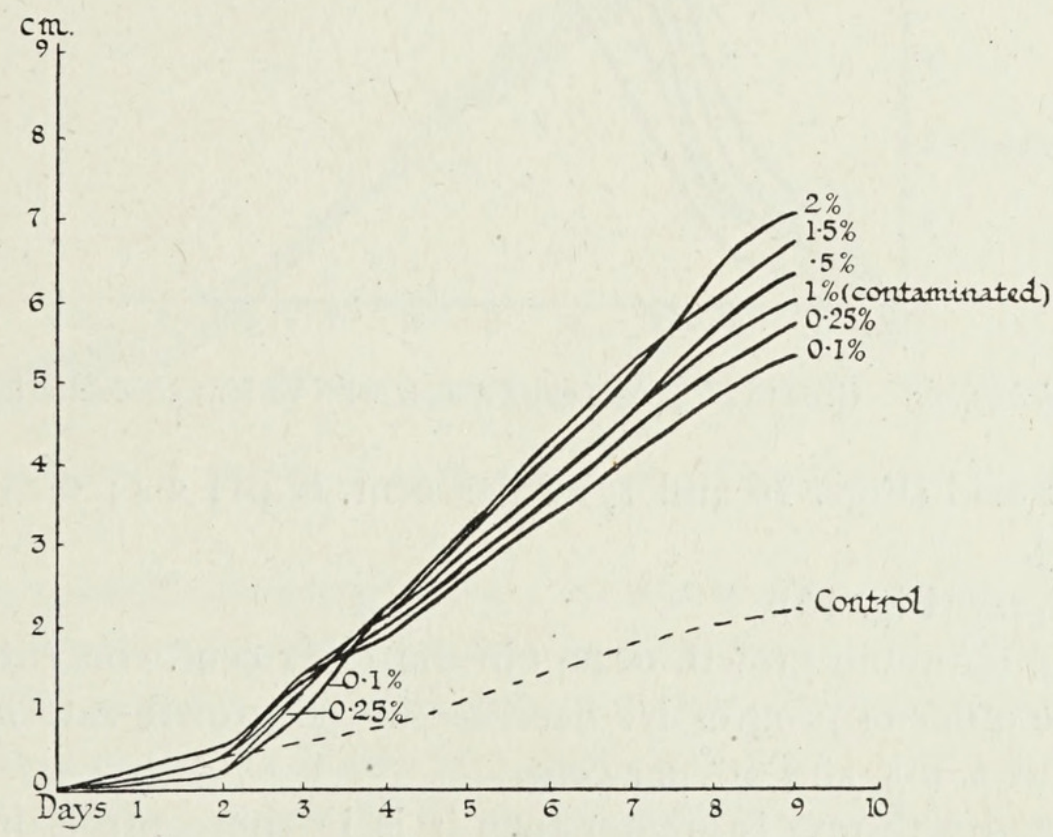

FIG. I4. E. catemulata. Growth on potato extract agar with various concentrations of malic acid.

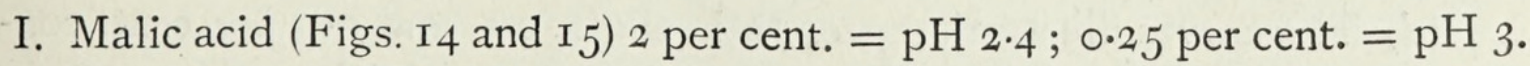
E. catemulata (Fig. 14).

(a) The optimum growth takes place in the 2 and $\mathrm{I} \cdot 5$ per cent. concentrations.

(b) The growth-rate decreases progressively when passing from the 2 to O. I per cent. concentration. 
(c) The growth-rate in all concentrations is considerably greater than it is in the controls $(\mathrm{pH} 7 \cdot 4)$.

E. viridescens (Fig. I5).

(a) The optimum growth takes place in the O.I per cent. concentration (hydrogen-ion concentration less than $\mathrm{pH} 3$ ).

(b) The growth-rate increases progressively when passing from the 2 to O.I per cent. concentration.

(c) The growth-rate is greater than it is in the control in all except the 2 per cent. concentration.

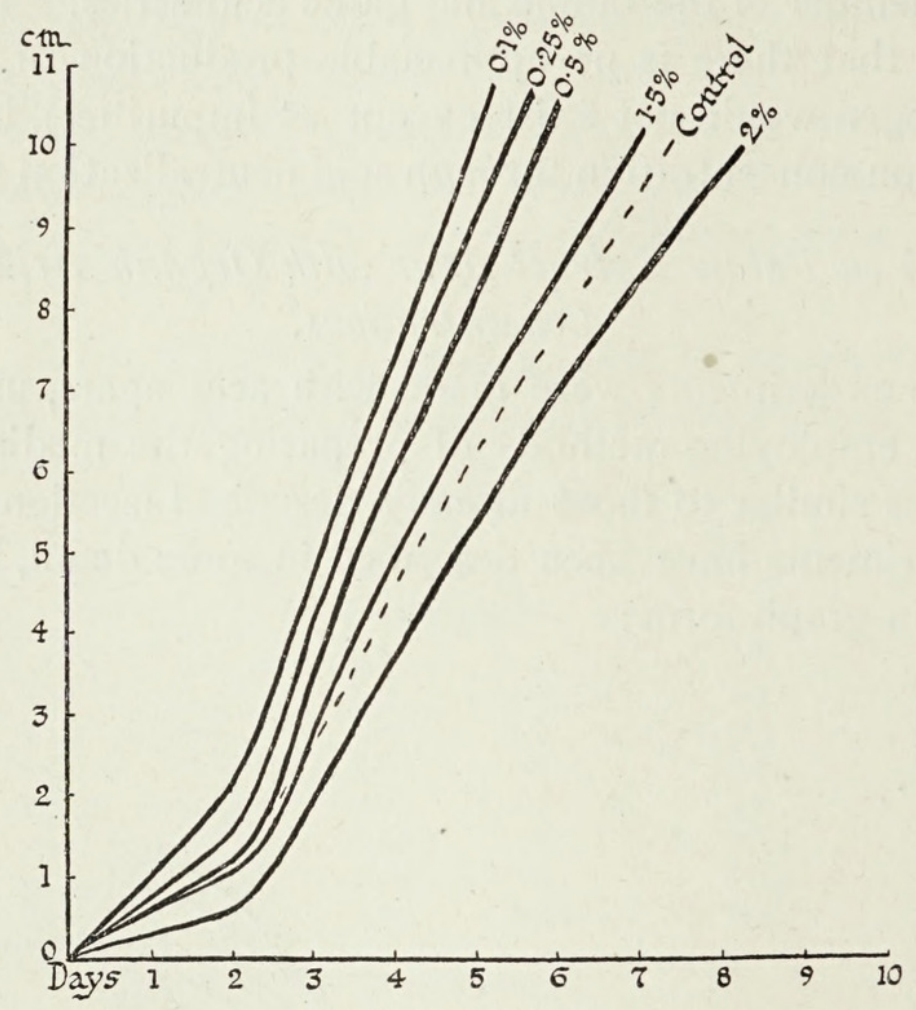

FIG. I5. E. viridescens. Growth on potato extract agar with various concentrations of malic acid.

II. Tartaric acid (Figs. I6 and I7) 2 per cent. $=$ pH $2.4 ; 0.25$ per cent. $=$ $\mathrm{pH} 3$.

E. catemulata (Fig. I6).

(a) The optimum growth occurs in the I per cent. concentration.

(b) The order of progressive decrease in the growth-rate is as follows: I, 2, 0.5 , and 0.1 per cent.

(c) The growth-rate is greater than it is in the controls in all concentrations.

(d) The curves illustrating growth in the $\mathrm{I}, 0.5$, and $0 . \mathrm{I}$ per cent. concentrations bend after the eighth day. As growth proceeds, both the acid concentration and the hydrogen-ion concentration of the media will be lowered, owing to the evolution of ammonia through the digestion of protein present in the potato extract, in addition to the lowering caused through utilization of acid. 
This change would produce progressive growth retardation, as the concentration falls away from that favoured by the fungus. Indications of this effect occur, according to expectation, first in the $0 . \mathrm{I}$ and 0.5 per cent. and later in the higher percentage concentrations. A similar phenomenon is exhibited with malic acid (Fig. I4).

E. viridescens (Fig. $\mathrm{I}_{7}$ ).

(a) The optimum growth occurs at a concentration of O.I per cent. (less than $\mathrm{pH}$ 3).

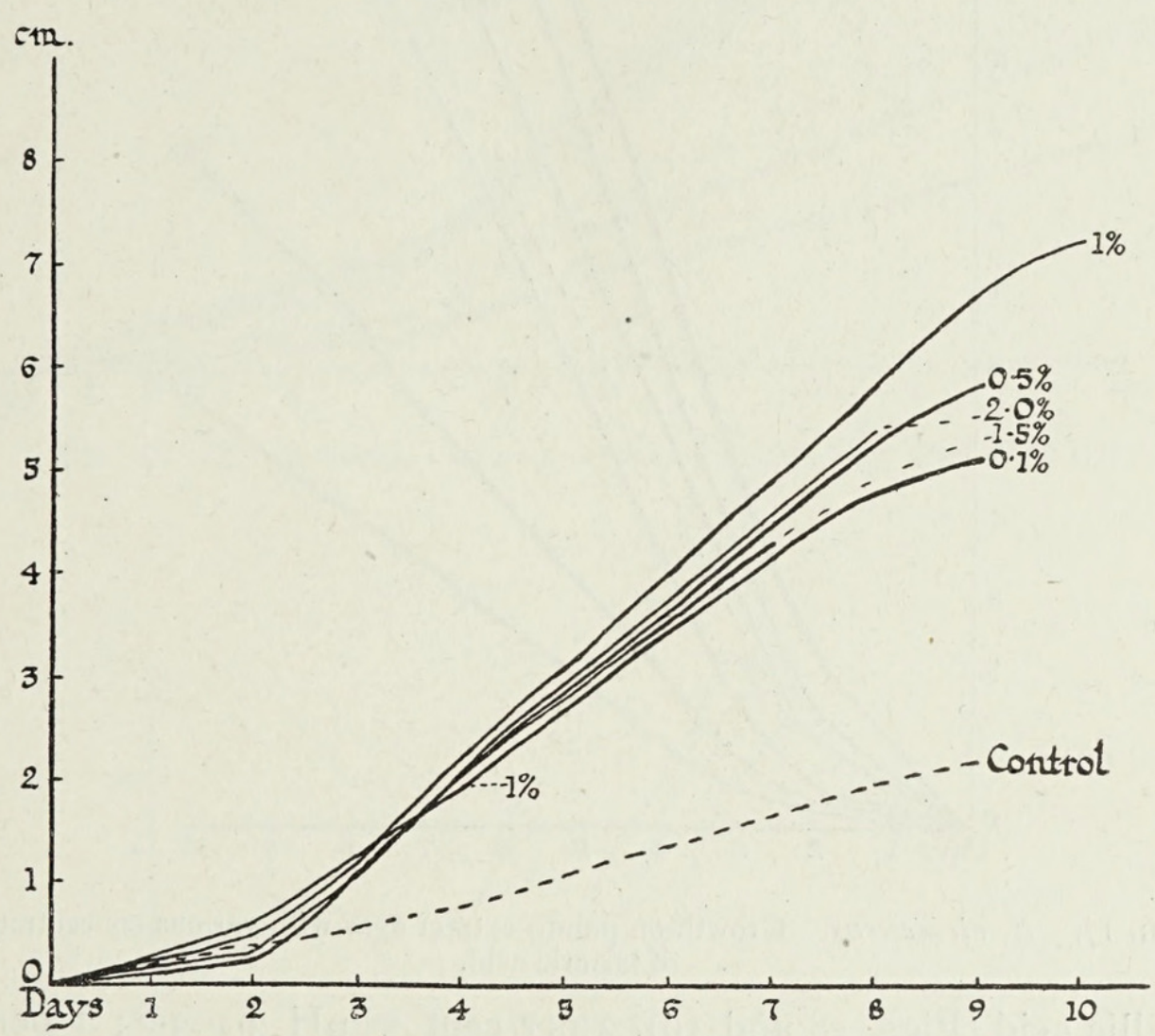

FIG. 16. E. catemulata. Growth on potato extract agar with various strengths of tartaric acid.

(b) The growth-rate progressively increases when passing from the 2 to O. I per cent. concentration, as with malic acid. With the exception of the 0.1 per cent. concentration, the growth-rate is less than it is in the corresponding malic acid series, and the difference is strongly marked in the $\mathrm{I}, \mathrm{I} \cdot 5$, and 2 per cent. concentrations.

(c) The growth-rate is less than it is in the controls in the I, I.5, and 2 per cent. concentrations.

(d) The curves do not bend downwards with the lowering of the concentration.

From these results it is clear that tartaric exercises a retarding influence on growth, as compared with malic acid, in media containing similar concentrations of these acids, the hydrogen-ion concentration being approxi- 
mately similar in each case. Also the two species of Eidamia react very differently towards these acids. The hydrogen-ion concentration favouring optimum growth is not far removed from $\mathrm{pH} 2.4$ (malic) for $E$. catenulata, and $\mathrm{pH}_{3}$ (malic) for $E$. viridescens. In the latter species the region of optimum growth does not appear to be sharply marked, and might possibly be represented by a curve exhibiting a gentle gradient towards the neutral point, but with a steeper descent on the acid side.

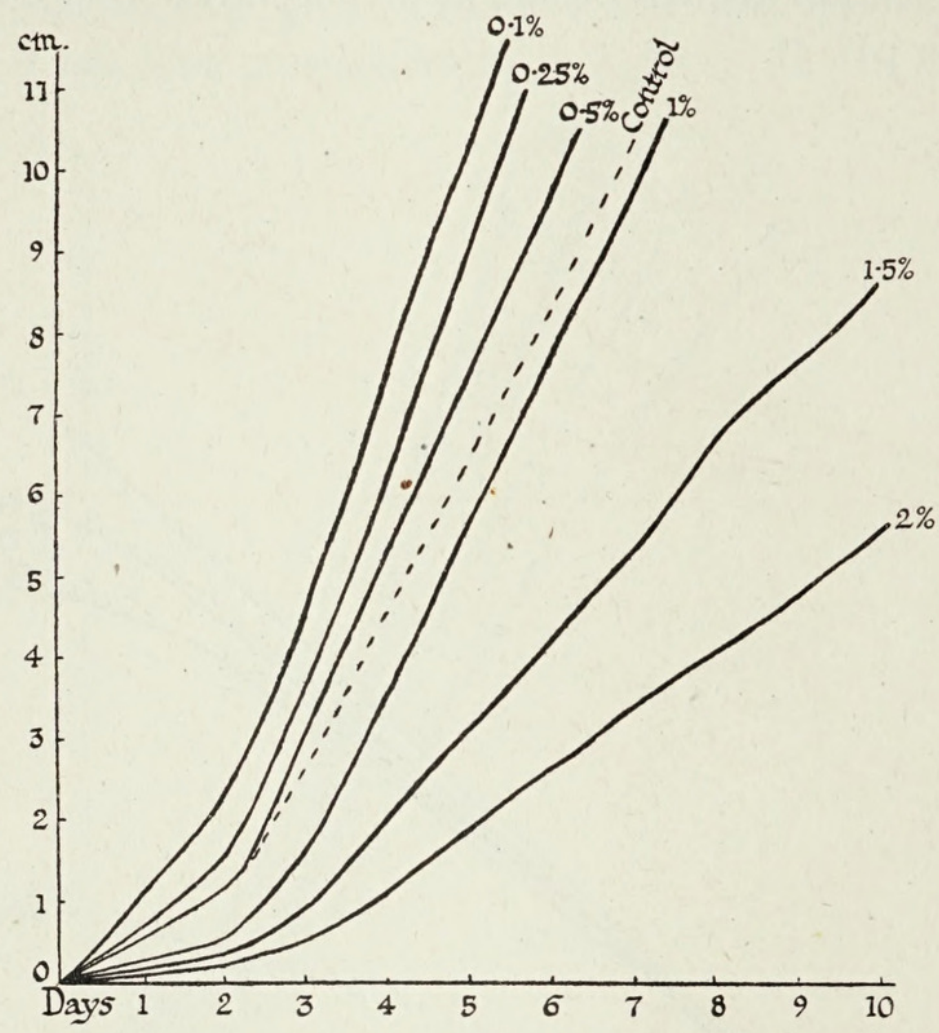

FIG. I7. E. viridescens. Growth on potato extract agar with various concentrations of tartaric acid.

III. Gallic acid (Figs. 18 and I9), 2 per cent. $=\mathrm{pH} 3 \cdot 4-3.6$; I per cent. $=$ $\mathrm{pH} 3.4-3.6$; 0.I per cent. $=\mathrm{pH} 4 \cdot 2$.

E. catenulata (Fig. I8).

(a) The optimum growth occurs at 0.5 per cent., but the curves of the $0.5,0.1,0.25$, and $I$ per cent. concentrations approximate closely.

(b) The growth-rate progressively decreases when passing from these to a 2 per cent. concentration.

(c) The growth-rate is greater than it is in the controls, in all except the $\mathrm{I} \cdot 5$ and 2 per cent. concentrations.

(d) In this last respect the curves differ from those obtained for malic and tartaric acids, but the hydrogen-ion concentration of the I. 5 and 2 per cent. gallic acid cultures is perhaps less favourable to the growth of E. catenulata than that of the corresponding. malic and tartaric acid series. 


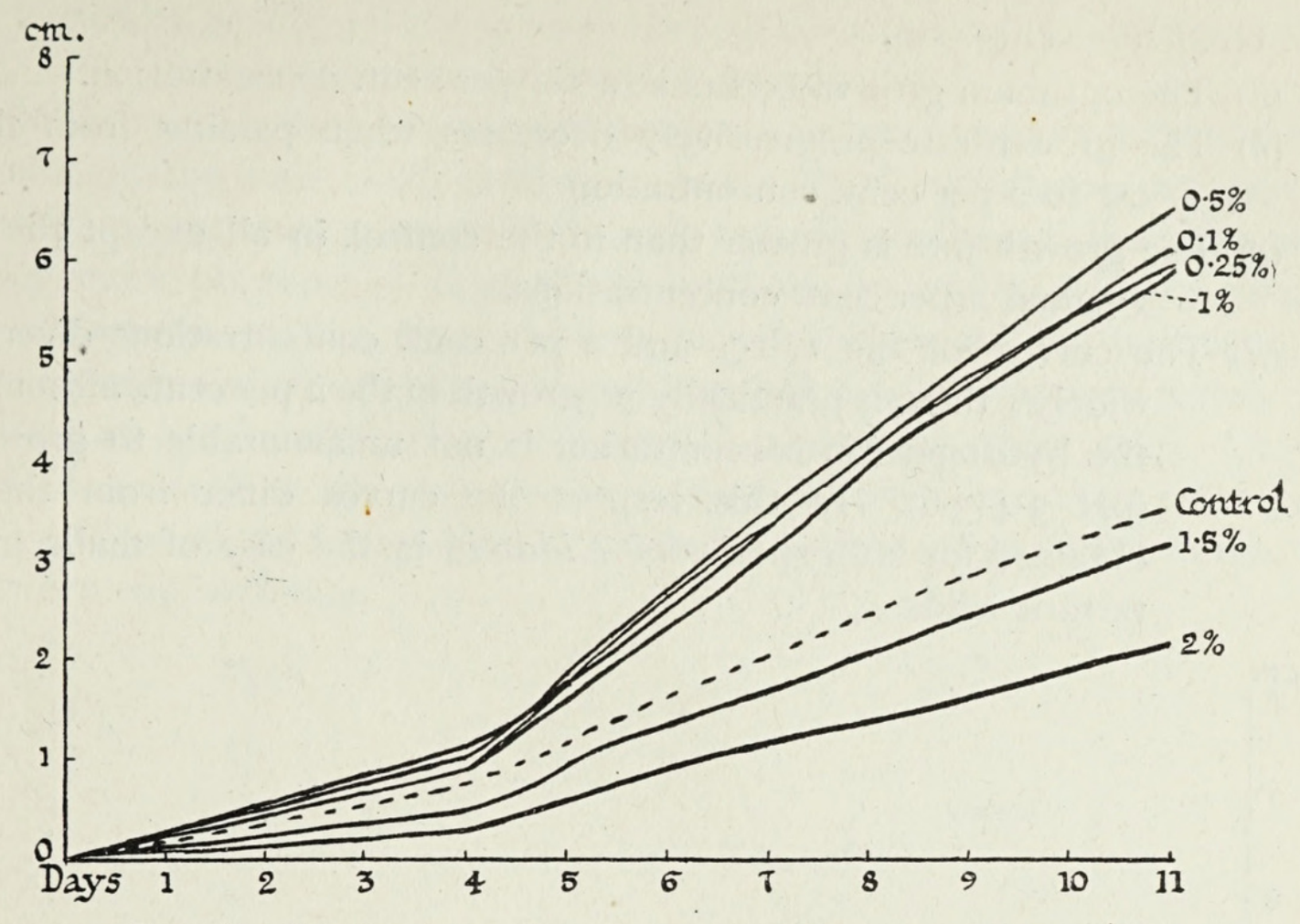

FIG. I8. E. catemulata. Growth on potato extract agar with gallic acid.

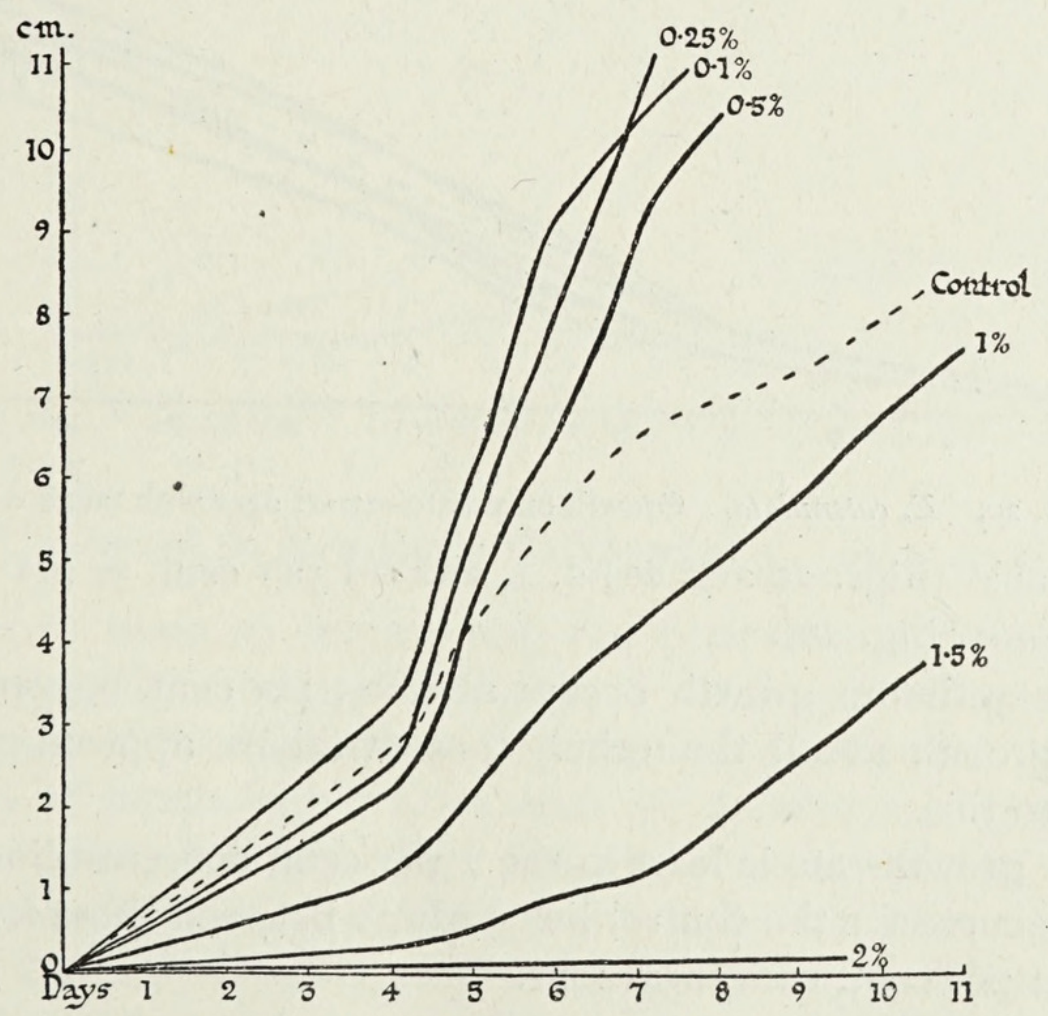

FIG. I9. E. viridescens. Growth on potato extract agar with gallic acid. 
E. viridescens (Fig. I9).

(a) The optimum growth occurs at a O.I per cent. concentration.

(b) The growth-rate progressively decreases when passing from the $0 \cdot$ I to 2 per cent. concentration.

(c) The growth-rate is greater than in the control, in all except the I, $1 \cdot 5$, and 2 per cent. concentrations.

(d) The curves for the I, I. 5 , and 2 per cent. concentrations diverge widely; there is practically no growth in the 2 per cent., although the hydrogen-ion concentration is not unfavourable to growth $(\mathrm{pH} 3 \cdot 4-3 \cdot 6)$. In this respect the curves differ from those obtained for both species of Eidamia in the case of malic and tartaric acids.

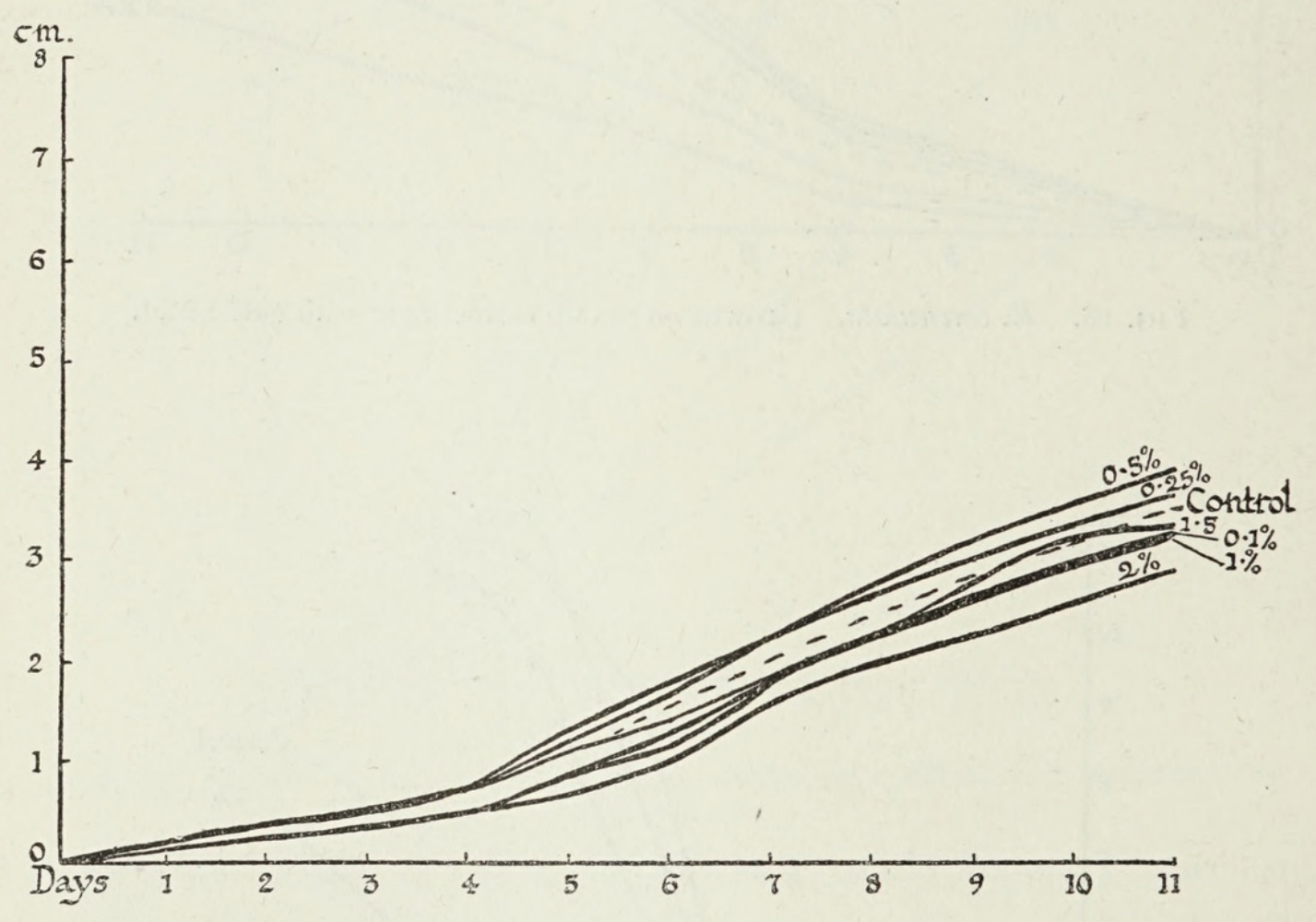

FIG. 20. E. catenulata. Growth on potato extract agar with tannic acid.

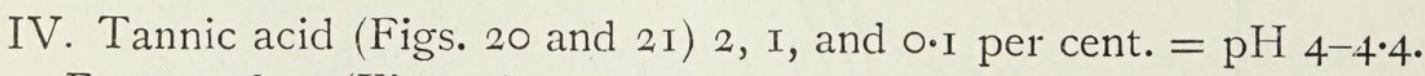
E. catemulata (Fig. 20).

(a) The optimum growth occurs at a 0.5 per cent. concentration, but growth at all the other concentrations approximates closely to this.

(b) The growth-rate is least in the 2 per cent. concentration.

(c) The curve for the control lies midway between those for the 0.5 and 2 per cent. concentrations.

E. viridescens (Fig. 2I).

(a) The optimum growth occurs at the O.I per cent. concentration.

(b) The growth-rate is retarded in concentrations higher than $\mathrm{O} \cdot \mathrm{I}$ per cent., with no growth beyond 0.5 per cent. 
(c) The growth-rate is greater than it is in the control in the $0 \cdot I$ per cent. concentration after the seventh day.

Tannic acid, in the concentrations used, appears to have little effect on growth in the case of $E$. catemulata, but with $E$. viridescens an increase beyond $\mathrm{O}$. I per cent. exercises a strongly retarding influence, the retardation being more pronounced than that exercised by gallic acid. Although $E$. viridescens exhibits these striking growth differences, the hydrogen-ion concentration of the tannic acid cultures $\left(\mathrm{pH}_{4-4.4)}\right.$ is approximately the same, and not inimical to growth (see E. viridescens, malic acid). Again, with $E$. catenulata the growth-rate is very different in $O^{\circ} \mathrm{I}$ per cent. gallic acid and tannic acid respectively, where the hydrogen-ion concentration lies between similar limits.

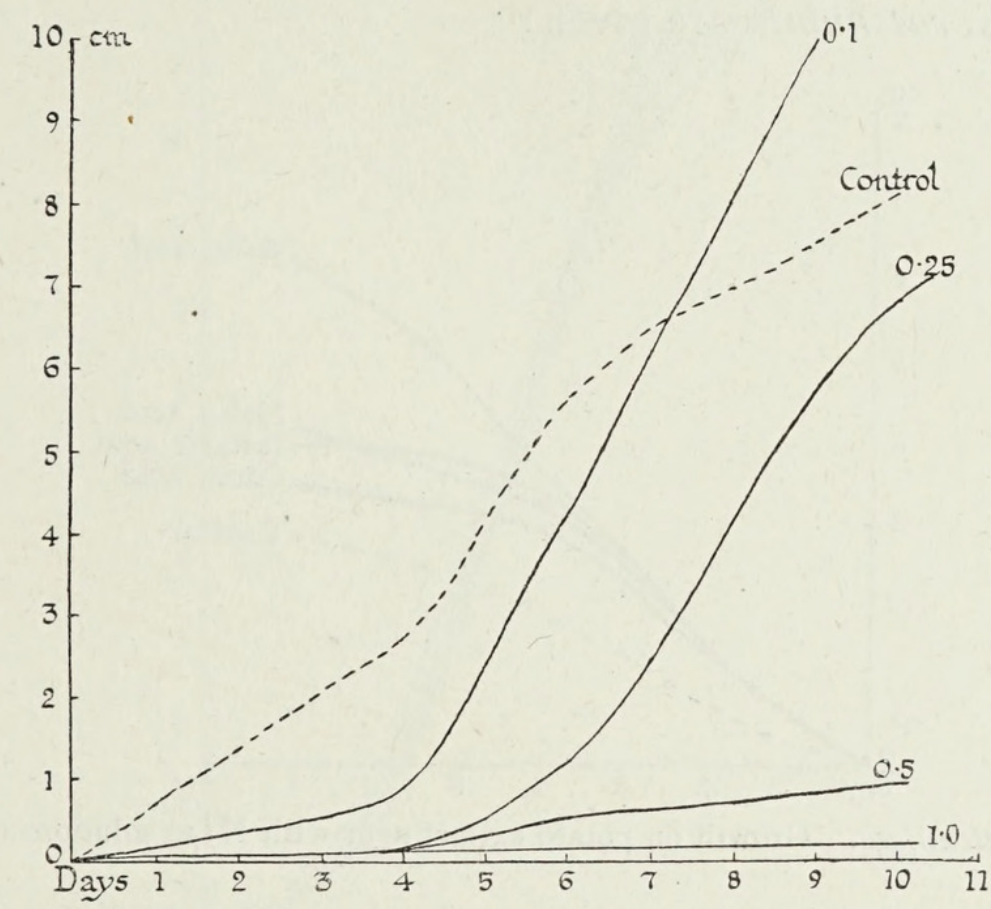

FIG. 2I. E. viridescens. Growth on potato extract agar with tannic acid.

\section{F. Growth in Equimolar Solutions of Organic Acids.}

In order to assist in interpreting the experimental results obtained through growing the species of Eidamia in media containing organic acid in percentage concentration, some preliminary experiments were set up, using a series of media with certain acids in equimolar proportions. For this purpose potato extract agar was prepared, containing $\mathrm{N} / 5^{\circ}$ citric, malic, tartaric, and gallic acids. Four lots of $\mathrm{I} c 0$ c.c. acid-containing media were prepared, using 80 c.c. of potato extract agar, and 20 c.c. of distilled water containing $(a) 0.268 \mathrm{grm}$. of malic acid, $(b) 0.3 \mathrm{grm}$. of tartaric acid, (c) $0.384 \mathrm{grm}$. of citric acid, and (d) $c .34 \mathrm{grm}$. of gallic acid respectively. The potato extract agar and the acid solutions were autoclaved separately, and the latter added to the extract afterwards. The $\mathrm{pH}$ values of the 
media, after final preparation and immediately before inoculation, were as follows :

\section{P.E. extract agar control}

,
,
,

, and malic acid .

$\mathrm{pH} 7 \cdot 0$

" citric acid .

, tartaric acid

, gallic acid.
„ 3.8

, $3 \cdot 4$

, 3.4
, $4 \cdot 2$

Series of plate cultures in duplicate were inoculated with E. catenulata and $E$. viridescens, and kept at $25^{\circ} \mathrm{C}$. and $20^{\circ} \mathrm{C}$. respectively. Growth data were recorded in the usual manner.

In order to show the extent of variation exhibited among members of a duplicate series, the actual growth measurements in centimetre diameter obtained for $E$. catenulata are given:

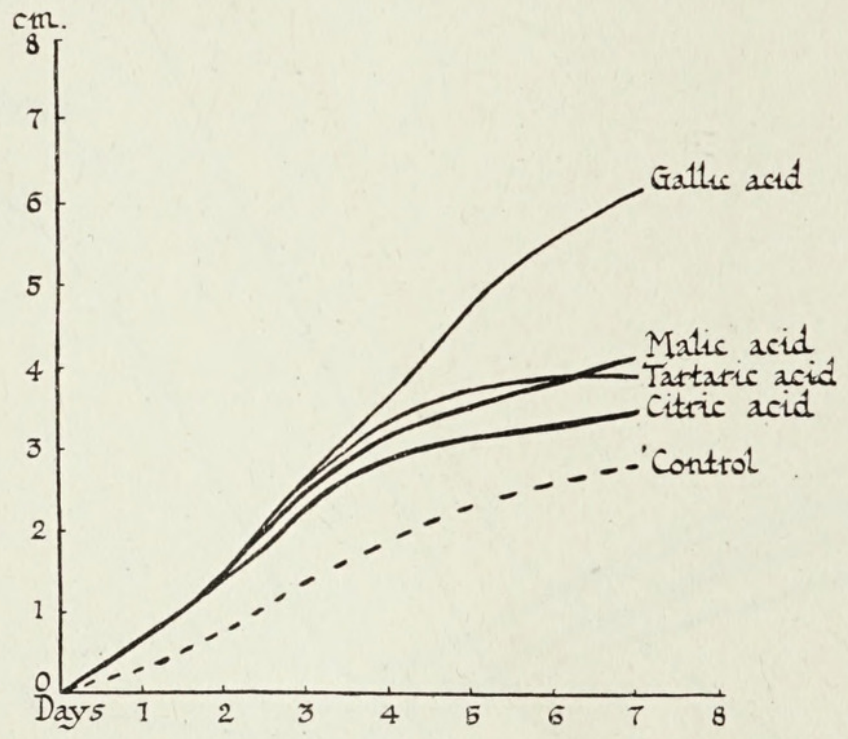

FIG. 22. E. catenulata. Growth on potato extract agar with $\mathrm{N} / 50$ solutions of various acids.

E. catenulata. Growth-rate in media containing N/50 organic acid.

Acid.

Citric

Malic

Tartaric

Gallic

Control
Series.

\begin{tabular}{ll}
\multicolumn{1}{c}{2} & \multicolumn{1}{c}{3} \\
$\mathrm{I} \cdot 45$ & $2 \cdot 5$ \\
$\mathrm{I} \cdot 45$ & $2 \cdot 4$ \\
$\mathrm{I} \cdot 45$ & 2.6 \\
$\mathrm{I} \cdot 5$ & $2 \cdot 5$ \\
$\mathrm{I} \cdot 55$ & 2.65 \\
$\mathrm{I} \cdot 5$ & $2 \cdot 7$ \\
$\mathrm{I} \cdot 6$ & $2 \cdot 7$ \\
$\mathrm{I} \cdot 5$ & 2.6 \\
0.75 & $\mathrm{I} \cdot 35$ \\
0.85 & $\mathrm{I} \cdot 5$
\end{tabular}

Interval in days.

$\begin{array}{lll}4 & 5 & 7 \\ 2.9 & 3.14 & 3.5 \\ 2.8 & - & 3.0^{1} \\ 3.3 & 3.6 & 4 \cdot 2 \\ 3.1 & 3.45 & 4 \cdot 1 \\ 3.3 & 3.55 & 3.9 \\ 3.4 & 3.75 & 3.9 \\ 3.6 & 4.681 & 6.1 \\ 3.65 & 4.9 & 6.6 \\ 1.8 & 2.5 & 2.8 \\ 1.8 & 2.5 & 2.8\end{array}$

The general conclusions deduced are as follows:

I. E. viridescens (Fig. 23) ( $\mathrm{pH}$ range of the media relatively favourable to growth).

1 The growth-rate in these cultures was affected by the appearance of additional colonies. 
(a) The curves for the control and acids practically coincide; the acids have exercised no appreciable effect on growth.

(b) After the second day, the growth-rate in each case is fairly uniform, as evidenced by the almost straight lines.

(c) After the fifth day the curves diverge, indicating that the growthrate is no longer uniform, and slightly decreased in the case of malic acid, tartaric acid, and the control. The retardation experienced coincides with a lowering of the hydrogen-ion concentration, but since the control was initially $\mathrm{pH} 7$, and it is unlikely that the acid-containing media would

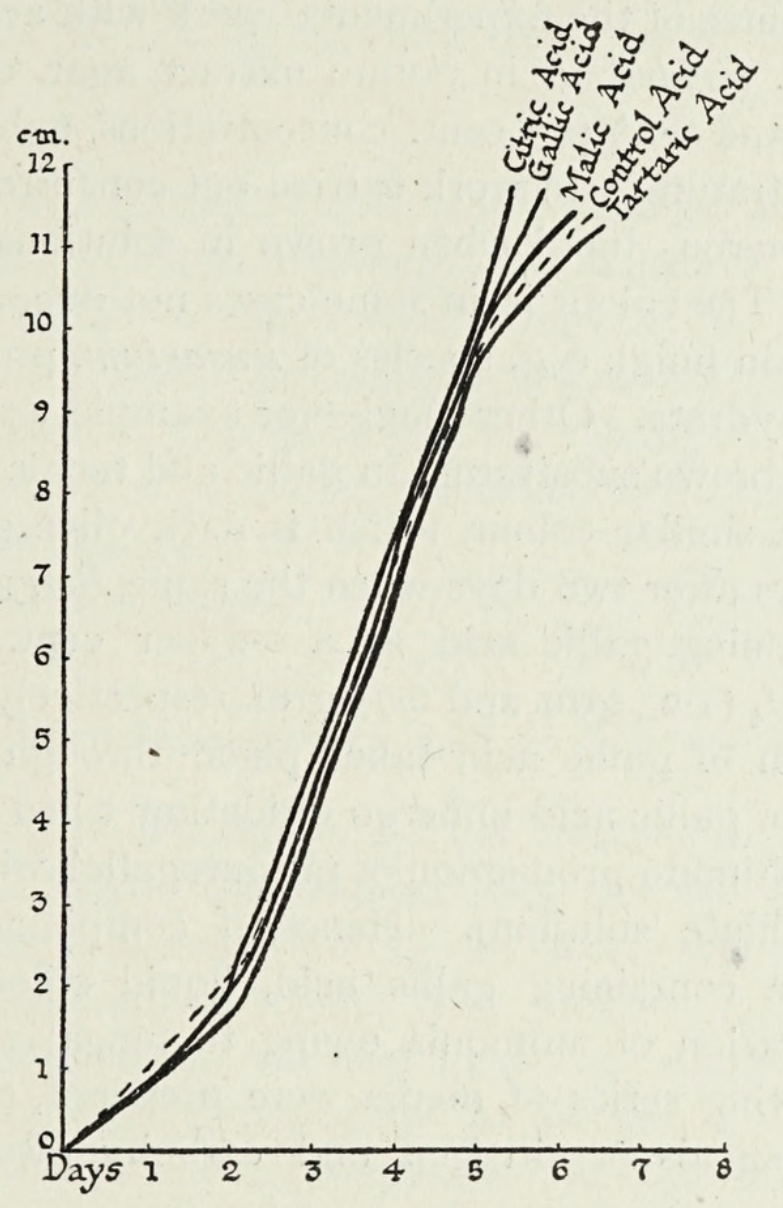

FIG. 23. E. viridescens. Growth on potato extract agar with $\mathrm{N} / 50$ solution of various acids.

exhibit greater alkalinity than the control, this retardation appears to be due to some other factor.

II. E. catenulata (Fig. 22) (pH range of the media relatively unfavourable to growth).

(a) The curve for the control (initially $\mathrm{pH}$ 7) falls below those for the acids.

(b) The curves for the acids diverge sharply after the third day, the gallic acid culture exhibiting the maximum growth-rate.

(c) The curves for citric and tartaric acids become depressed after the third and fourth days respectively. E. catenulata is highly tolerant of acid, hence the lowering of the hydrogen-ion concentration should cause growth 
retardation. The divergence of the curves, however, is not so easily explained; the effect seems to be due to the toxicity of the acids in question.

(d) The growth-rate is least in the citric acid culture, the reverse of the result obtained with $E$. viridescens.

\section{G. Colour Production in Media containing Gallic or Tannic Acid.}

During the course of the experimental work with acids, it was observed that cultures of $E$. viridescens in potato extract agar, containing gallic or tannic acid in 0.1 and 0.25 per cent. concentrations, exhibited a deep green colour in the substratum. In work carried out concurrently coloration was obtained with numerous fungi when grown in solutions containing 0.2 per cent. gallic acid. The colour is in some cases not due, or not entirely due to acid, since certain fungi, e.g. species of Fusarium, produce colours in the presence of carbohydrate. Other fungi-for example, a species of Botrytisproduce a reddish brown substratum in gallic and tannic acid potato extract plate cultures. A similar colour, which is dark olive green when diluted with water, appears after two days when the same Botrytis is kept at $20^{\circ} \mathrm{C}$. in solutions containing gallic acid at a 0.2 per cent. concentration, and $\mathrm{K}_{3} \mathrm{PO}_{4}$ and $\mathrm{MgSO}_{4}(\mathrm{I} \cdot 25 \mathrm{grm}$. and $0.75 \mathrm{grm}$. respectively per litre). In this case the oxidation of gallic acid takes place through enzymatic action. Again, solutions of gallic acid undergo oxidation when alkali is present in excess, with the ultimate production of purpurogallol, which is of a brownish olive colour (in dilute solution). Hence, if compounds of nitrogen are present in media containing gallic acid, liquid coloration might ensue through the liberation of ammonia owing to fungal activity. For these reasons, the following series of media were prepared, containing members from which compounds of nitrogen and carbohydrate respectively were omitted:

I. $\mathrm{K}_{3} \mathrm{PO}_{4}, \mathrm{I} \cdot 25$ grm.; $\mathrm{MgSO}_{4}$, 0.75 grm.; asparagin, 2 grm. ; glucose, 2 grm. per litre.

2. As in No. I, with glucose omitted.

3. As in No. I, with asparagin omitted.

4. As in No. I, with both glucose and asparagin omitted.

To each of these, ro c.c. of a 2 per cent. solution of sterile gallic acid were added after autoclaving. Flasks (capacity 250 c.c.), containing Ioo c.c. of liquid (pale yellow in colour), were inoculated with the three species of Eidamia, and these, together with the necessary controls, were kept at $20^{\circ} \mathrm{C}$.

With $E$. acremonioides no growth was obtained in solution I after two days and the experiment was discontinued. In the case of E. catemulata and $E$. viridescens colour appeared in the solutions containing asparagin. 
After the appearance of colour the solution when tested with litmus paper proved to be alkaline.

The more detailed results are as follows :

E. viridescens.

Seventh day. No. 2, liquid olive green with suggestion of reddishbrown, alkaline, ammonia present. No. I, liquid without colour change, acid. Nos. 3 and 4, little growth, liquid without colour change, acid.

Tenth day. No. I, liquid port wine colour, alkaline, ammonia present. Nos. 3 and 4 , no noteworthy change.

Thirteenth day. No. I, liquid dark olive green. Nos. 3 and 4 , no noteworthy change.

E. catenulata.

Seventh day. No. 2, liquid without colour change, acid. No. I, liquid slightly darker in colour, slight alkalinity, ammonia not detected. Nos. 3 and 4 , little growth, liquid without colour change, acid.

Tenth day. No. I, further darkening in colour to light brown, alkaline, ammonia present. Nos. 2, 3, 4, no noteworthy change.

Fourteenth day. Nos. I and 2, solutions port wine colour. Nos. 3 and 4 , no noteworthy change.

Controls. Liquid unchanged.

\section{H. General Conclusions on Growth in Relation to Acids.}

Since the behaviour of fungi in special relation to acids needs more detailed investigation than this subject has received hitherto, it is not advisable to enter into a discussion of all the factors influencing the growth of the species of Eidamia in acids. The present object will be better attained by expressing in summarized form the results which appear to have a general bearing on fungal work of this nature.

I. Both E. catemulata and E. viridescens are capable of utilizing certain organic acids; the power of utilization appears to be increased when the medium contains other sources of nutriment.

2. These species, unlike Penicillium glaucum, do not markedly utilize one only of the two stereo-isomers present in racemic acid.

3. In a general way hydrogen-ion concentration exercises a regulating influence on growth, the degree of its influence varying with the nature of the constituents of the medium employed.

4. Growth in any medium containing acid and compounds of nitrogen may be progressively affected by three factors :

(a) utilization of acid;

(b) neutralization of acid through evolution of ammonia ;

(c) acid production through fermentation of sugar.

Where the general trend is towards alkalinity, both the molecular con- 
centration of the acid and hydrogen-ion concentration of the medium will be lowered. In the case of a species highly tolerant of acid, these factors sooner or later exercise a retarding influence on growth: if the species is relatively intolerant, growth might be accelerated (E. viridescens is moderately tolerant).

5. In the sections of this paper relating to growth in acids many cases have been specified where fungal growth does not appear to bear any definite relation to hydrogen-ion concentration. This behaviour may be due in part to differences in molecular concentration. Tannic acid (molecular weight I785) affects the growth of $E$. viridescens considerably more than gallic acid (I88), although the hydrogen-ion concentration of the tannic acid media is more favourable to growth than that of the gallic acid. Tartaric acid (168) affects both $E$. viridescens and E. catemulata more than malic acid (134). Further support is obtained from the growth data determined for $E$. viridescens in the tannic extract agar series (Fig. $2 \mathrm{I}$ ); here the curves for the $0.1,0.25,0.5$, and I per cent. concentrations exhibit great dissimilarity, the progressive retarding influence on growth being strikingly correlated with increased molecular concentration.

6. In media containing $\mathrm{N} / 50$ malic, citric, tartaric, and gallic acids respectively, the growth-rate is approximately the same for $E$. viridescens: it is the same for a few days, but differs later, in the case of E. catemulata. Variations of this kind in the growth-rate in equimolar concentrations of acids may be due, in part, to changes in the media owing to growth activities which may vary in character with the acid employed. On the other hand, some acids may exercise a specific toxic action, at particular molecular concentrations, on a given fungus, in which case a somewhat similar effect would be produced.

\section{Systematic Position and Specific Descriptions.}

The general characteristics of the genus Eidamia as proposed by Lindau (11) are: hyphae branched, septate, white; conidiophore upright, branched, septate, narrow at the apex and bearing a circular swollen end cell; sterigmata arising radially on the swollen head, pointed; conidia in chains, hyaline; bulbils produced on side branches and branches similar to the conidiophores produce single-celled chlamydospores of rounded form and yellow-brown colour.

Up to the present time only one species, possessing all these characteristics, has been included in the genus, viz. E. acremonioides. The writers consider the inclusion of the two new fungi, E. catemulata and $E$. viridescens, in this genus is justifiable on the grounds of their general resemblance to $E$. acremonioides in possessing colourless branched septate hyphae producing two types of spores, namely conidia and single-celled macrospores 
borne terminally on lateral branches. The differences lie in the form of the conidiophore, the appearance of the conidia in groups in the case of E. viridescens, and the fact that the macrospores are hyaline instead of brown in both fungi. It can be shown that these differences break down when growth takes place on different media.

The conidiophore of E. acremonioides is typically of the Aspergillus form, the globular apical portion bearing sterigmata with spores in chains. Under certain cultural conditions the sterigmata are borne, either singly or in small lateral or terminal groups, on undifferentiated branch hyphae. When Fig. 3 (E. acremonioides) is compared with those illustrating the conidiophores of $E$. viridescens the similarity in position of the sterigmata and their size and shape is very striking. In the case of E. catenulata the conidiophores are usually not apically swollen, but approximations to the types found in E. acremonioides do occur (Fig. IO).

In Eidamia the conidia are typically borne in chains, but, even in the case of $E$. acremonioides, a disposition in groups at the apices of the sterigmata is not uncommon. In E. viridescens grouping is the rule and catenulate conidia are rare. From the occurrence of intermediate stages (Fig. I2, E. catenulata) a distinction between chains and groups of spores as a criterion of specific value is of little importance in the genus Eidamia. The conidia in the two new fungi are coloured in contrast to the colourless state of those of $E$. acremonioides, but this difference is not of generic value.

The macrospores of $E$. acremonioides are relatively larger than those of the other two species. They are usually brown in colour as contrasted with the lack of colour in E. catenulata and E. viridescens, though occasionally hyaline spores are produced (potato mush agar at $30^{\circ} \mathrm{C}$. or potato slab at $25^{\circ} \mathrm{C}$.). Therefore the two new fungi cannot be excluded from the genus owing to the hyaline character of the macrospores. From the foregoing it will be seen that the differences between the three fungi are not of sufficient importance to prevent their inclusion in one genus.

The bulbils found in E. acremonioides (Papulaspora aspergilliformis) and in Helicosporangium parasiticum by Eidam (6) are regarded by Bainier (1) as perithecia containing an ascogonium capable of developing to form a typical perithecium, with ascospores set at liberty through an ostiole. Normally the development appears to be arrested when the bulbils contain central cells surrounded by a sheath. After resting, such a bulbil is capable of growth by the production of vegetative filaments. Moreau (12) has worked out the cytology of these structures, and his conclusion supports Eidam and Bainier in the view that the bulbils are perithecia arrested in their development, not abortive, but capable of proceeding with the normal formation of a perithecium under certain conditions. No bulbils were found in $E$. acremonioides on the media used in this investigation, nor was their presence detected in E. catemulata and E. viridescens. 
These two new species show certain resemblances to Verticillium in form and arrangement of conidiophores, whilst E. catenulata sometimes produces a typical Penicillium form of conidiophore. They are separated from Verticillium and Penicillium by their possession of a second type of spore which is a constant feature in both of them.

The genus Papulaspora, originated by Preuss (16), includes many forms with bulbils which have been named without reference to the existence of any other form of reproduction; for example, Papulaspora magnificus, Hotson (8), was found to be an asexual stage of Ascobolus magnificus, and Dodge $(5)$ has shown that sexual reproduction occurs in cultures containing two strains properly chosen. As the genus at present stands there are at least nine species of Papulaspora as yet unconnected with any perfect form. Moreau suggests that the nomenclature proposed by Lindau should be adopted and all fungi with bulbils of the type of Papulaspora aspergilliformis should be classed as Eidamia. Papulaspora aspergilliformis is synonymous with E. acremonioides.

The case of Helicosporangium parasiticum is also of interest in this connexion. A fungus was described and given this name in 1865 by Karsten (10). In $188_{3}$ Eidam (6) described a form which he called by the same name, but it is very probable that the Helicosporangium of Karsten and the Helicosporangium of Eidam are not the same fungus. Eidam describes his fungus as possessing bulbils exactly like those of Eidamia acremonioides. $\mathrm{He}$ further figures the sterigma as a single-celled flask-shaped body borne singly on a hypha or in groups on a conidiophore. The figures of these conidiophores are markedly like those represented in Fig. 3 for E. acremonioides. Eidam does not mention the formation of any 'chlamydospores'. Bainier (1) objects to the separation of Helicosporangium parasiticum from Papulaspora aspergilliformis ( $E$. acremonioides) on the ground that it is a 'monstrous form' that the Mucedineae often present. With the facts in mind of the variation presented by $E$. acremonioicies when grown on different media, the writers are inclined to agree with Bainier and to regard Helicosporangium parasiticum as probably synonymous with Eidamia acremonioides. Possibly in the case of $H$.parasiticum the macrospore was overlooked or was absent from the particular medium on which the fungus was growing.

Large brown spores were found on seeds of Festuca pratensis by A. L. Smith (19). These were borne singly on the ends of branches on a colourless mycelium and were named Langloisula macrospora by Smith on account of their resemblance to Langloisula spinosa, Ellis and Everhart. Smith suggested that this genus rests on too narrow a foundation and should be included with Acremoniella. Later Pethybridge (15) cultured the same fungus from brown spores occurring on blighted potato foliage. He noted the peculiar branching, recalling that of Monopodium, and sent the specimen to Paris for comparison with $M$. uredopsis, Delacroix (4). 
There M. Arnaud suggested that both Monopodium and Langloisula macrospora are probably identical with Acremoniella atra, Corda (3). By the courtesy of the Cryptogamic Department of the British Museum (Natural History) the slides of Langloisula macrospora made by Smith and Pethybridge have been examined. They appear to be identical with Eidamia acremonioides when only the mycelium, pseudosympodial branches, and brown macrospores are present, as is the case when the fungus is grown on rice at $20^{\circ} \mathrm{C}$., potato slab at $25^{\circ} \mathrm{C}$., and potato mush agar at $30^{\circ} \mathrm{C}$. Acremoniella atra, as figured by Saccardo (17), exhibits this peculiar type of branching and also apically borne brown spores, $25^{-28} \mu$ long by $16-18 \mu$ wide, resembling the macrospores of $E$. acremonioides. Langloisula spinosa, Ellis and Everhart, is regarded by von Höhnel (7) as belonging to the Corticiae, being only separated from Asterostromella by the colour of the spores. The writers have had no opportunity of examining L. spinosa, but consider that L. macrospora is certainly a Hyphomycete with a remarkable resemblance to $E$. acremonioides in the macrospore stage.

It seems probable then that Langloisula macrospora, A. L. Smith, Monopodium uredopsis, Delacroix, and Acremoniella atra, Corda, are identical, and may ultimately prove to be synonymous with Eidamia acremonioides.

The following revised description of the genus Eidamia is suggested :Hyphae branched, septate, white; conidiophore upright, branched or unbranched, septate, bearing a swollen cell with sterigmata, or the sterigmata may be borne singly or in groups on the unbranched or branched conidiophore; conidia in chains or groups, hyaline or coloured: branches similar to the conidiophore produce single-celled macrospores of round or ovoid form, yellow brown or colourless; infertile perithecia (bulbils) present or absent.

Eidamia acremonioides, Harz.

Syn. Monosporium acremonioides. Harz in Bull. Soc. Imp. Sci. Natur. Moscou, xliv, I (I87 I), p. I04, Tab. I, Fig. 3 ; Bot. Centralbl., xli (1890), p. 4I0; Sacc. Syll., iv, p. I I5.

Papulaspora aspergilliformis. Eidam in Cohn's Beitr., iii (I883), p. 4 II, Tab. XXIII, Figs. 7 to I 7 ; Sacc., Syll., ix, p. 339.

Helicosporangium parasiticum. Eidam in Cohn's Beitr., iii (I883). p. 4I 4 , Tab. XXIII.

Mycelium spreading, pseudo-sympodial branching, septate, white; conidiophores hyaline, often branched, septate, $3-4 \mathrm{~mm}$. high, mostly smaller, Io $\mu$ broad at base by $6.5 \mu$ at apex, often bearing swollen cell of $12-13 \mu$ diameter; sterigmata flask-shaped, $6 \mu$ long by $4 \mu$ wide at base, borne on the swollen cell or singly or in groups directly on the hyphae of the conidiophore; conidia in chains or groups, hyaline, circular or egg-shaped, $\mathbf{I} \cdot 5^{-2} \mu$ in diameter; bulbils may occur on side branches ; macrospores formed singly 
and terminally on branches, yellow brown, thick-walled, circular or ovoid, I 2 by $10 \mu$ to 40 by $34 \mu$.

\section{Eidamia catemulata, n. sp.}

Mycelium hyalinum, septatum, ramosum, 3-II $\mu$ latum; conidiophora erecta, simplicia vel ramosa, septata ; sterigmata gracilia, ad basim turgidius-

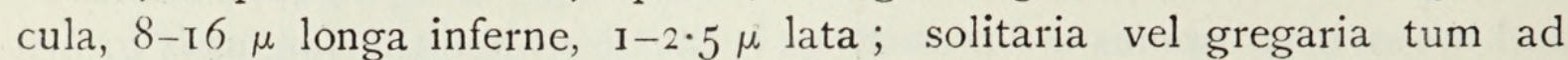
hypham simpliciam tum ad apices ramorum conidiophoreorum vel gregaria ad apicem rami brevis turgidi sita; conidia catenulata (circa centena), flava anguste vel late elliptica, utrinque acuta, $4-7 \times 2-3.5 \mu$, interdum ad apicem sterigmatis aggregata; macrosporae hyalinae, solitariae vel binae ad apicem rami brevis tum intercalaris, pachydermaticae, subglobosae, $7 \cdot 5 \times$ $8.5 \mu$, vel pyriformes, $\mathrm{I} 4 \times$ Io-1 $8 \mu$.

Hab. in ligno exsiccato quercus.

Eidamia viridescens, n. sp.

Mycelium hyalinum, septatum e hyphis ramosis 7 -I I $\mu$ latis compositum; conidiophora ramosa, septata; sterigmata lageniformia, 8-20 $\mu$ longa inferne, $\mathrm{I} \cdot 5-3 \mu$ lata, solitaria vel gregaria, praeter conidiophori ramos disposita; conidia aggregata vel breviter catenulata, flavida aut viridia, subovoidea, $4 \times 5 \mu$, vel ellipsoidea, $2.5 \times 4 \mu$, vel sphaerica, $4.5 \mu$ diam.; macrosporae hyalinae, tum solitariae ad apices ramorum lateralium, tum intercalares, pachydermaticae, subglobosae, 1 I $\times 8 \mu$, vel ovoideae, I $3 \times$ 9-I $2 \mu$.

Hab. in malis putridis.

\section{Physiological Characters.}

1. The approximate temperature optima are as follows : E. acremonioides, $20^{\circ} \mathrm{C}$.; E. viridescens, $25^{\circ} \mathrm{C}$.; E. catenulata, $30^{\circ} \mathrm{C}$.

2. Whereas $E$. acremonioides produced growth of a relatively feeble character the remaining species responded freely to a wide range of nutritive conditions. The growth-rate of $E$. viridescens is much greater than that of $E$. catemulata when the species are grown at their respective temperature optima, other conditions being constant.

3. E. catenulata and E. viridescens hydrolyse starch, invert sucrose, decompose protein and asparagin with evolution of ammonia, and ferment certain sugars with acid production in the presence of protein. In these respects they differ markedly from $E$. acremonioides.

4. In the presence of carbohydrate, $E$. viridescens produces a volatile compound with an odour recalling that of coco-nut oil.

5. No growth was obtained on cellulose.

6. Unlike $E$. acremonioides the remaining species are able to utilize soluble pectin. 
7. The growth-limits in relation to hydrogen-ion concentration for the media used are as follows:

$$
\begin{array}{ll}
\text { E. catemulata } & \mathrm{pH} \mathrm{I}_{1} 6 \text { and } \mathrm{pH} 8 \cdot 2, \\
\text { E. viridescens } & \mathrm{pH} 2 \text { and } \mathrm{pH} 8 \cdot 2, \\
E \text {. acremonioides } & \mathrm{pH} 3 \text { approx. and } \mathrm{pH} 8 .
\end{array}
$$

8. E. catenulata and E. viridescens utilize certain organic acids; the reaction is regarded as analogous to bacterial fermentations of acids.

9. Hydrogen-ion concentration exercises a regulating effect on growth : the growth reactions obtained with the species of Eidamia bear a definite relation to the relative degree of acid tolerance exhibited by them.

I0. Growth retardation is often correlated with increased molecular concentration (acids): E. catemulata and E. viridescens differ in their response to altered molecular concentration.

I1. The coloration ultimately appearing in certain cultures of E. viridescens and E. catemulata containing gallic acid and protein is due to the oxidation of the acid owing to the presence of free alkali.

I2. The principle causing spore coloration in E. catemulata and $E$. viridescens is insoluble in ether, chloroform, and the usual solvents.

13. E. viridescens is parasitic on apples at $\mathrm{I}^{\circ} \mathrm{C}$., and at ordinary laboratory temperatures E. catenulata and E. acremonioides are saprophytic.

\section{Summary.}

The salient morphological features of three species of Eidamia, including two which are apparently new to science, are described. The reactions which these species exhibit when grown in various media, including sugars, soluble pectin, protein, organic acids, and various other substances, are compared and contrasted. The growth-limits of the species in relation to hydrogen-ion concentration are approximately determined.

The authors are greatly indebted to Professor V. H. Blackman for his very kind advice and criticisms, and to Mr. A. B. Manning for help in matters relating to physical chemistry; also to Mr. J. Ramsbottom of the British Museum (Natural History) for assistance in connexion with the systematics of Eidamia and for the specific descriptions.

This work was undertaken in connexion with investigations now being carried out for the Food Investigation Board of the Department of Scientific and Industrial Research. 


\section{LiterATURE CITED.}

1. Bainier, G.: Évolution du Papulaspora aspergilliformis et étnde de deux Ascodesmis nouveaux. Bull. Soc. Myc. Fr., xxiii. I32, 1907.

2. Carré, M. H., and Haynes, D.: On the Estimation of Pectin as Calcium Pectate and the Application of this Method to the Determination of the Soluble Pectin in Apples. Biochem. Journ., xvi. 6o, 1922.

3. Corda, A. C. J.: Icones Fungorum, i. I i, Tab. 3, No. 168.

4. Delacroix, G.: Quelques espèces nouvelles de Champignons inférieurs. Bull. Soc. Myc. Fr., vi. $99, \mathrm{I} 890$.

5. Dodge, B. O.: The Life-history of Ascobolus magnificus. Mycologia, xii. I15, I912.

6. Eidam, E. : Zur Kenntniss der Entwicklung bei den Ascomyceten. Cohn's Beiträge, iii. 4r r, $4 \mathrm{I} 4, \mathrm{I} 88_{3}$.

7. Höhnel, F. von : Fragmente zur Mykologie, No. i155. Sitzb. Akad. Wissenschaft. Wien, cxxviii. 537, I 9 I 9 .

8. Hotson, J. W. : Culture Studies of Fungi producing Bulbils and similar Propagative Bodies. Proc. Amer. Acad., xlviii. 228, I9I2-I3.

9.

10. Karsten, $\bar{H}$.: Bot. Untersuch. a. d. phys. Laborat. Berlin, i, 1865.

11. Lindau, G.: In Rabenhorst, Krypt.-Fl., Pilze, viii. I 23. I $904-7$.

12. Moreau, F. : Signification des Bulbilles des Eidamia. Bull. Soc. Bot. Fr., lxiv. 71 , I91 7 .

13. Pasteur, L. : Note relative au Penicillium glaucum et à la dissymétrie moléculaire des produits organiques naturels. Comptes Rendus, li. 298, I860.

14. Peltier, G. L. : Influence of Temperature and Humidity on the Growth of Pseudomonas citri and its Host Plants and on Infection and Development of the Disease. Journ. Agric. Sci., xx. 448,1920 .

15. Pethybridge, G. H. : Notes on some Saprophytic Species of Fungi associated with Diseased Potato Plants and Tubers. Brit. Myc. Soc., vi. iा 7 , igig.

16. Preuss, J.: In Sturm, Deutschlands Flora, iii. 90, $1848-5$ I.

17. SACCARDo, P. A. : Fungi Italici, tab. 7І 3 , I88 I.

18. : Sylloge Fungorum, iv. 302, I 886.

19. Smith, A. L. : The Fungi of Germinating Farm Seeds. Brit. Myc. Soc., i. I $8_{5}$, I 902. 


\section{$2 \mathrm{BHL}$ Biodiversity Heritage Library}

Horne, A. S. and Williamson, H. S. 1923. "The morphology and physiology of the genus Eidamia." Annals of botany 37, 393-432. https://doi.org/10.1093/oxfordjournals.aob.a089856.

View This Item Online: https://www.biodiversitylibrary.org/item/270686

DOI: https://doi.org/10.1093/oxfordjournals.aob.a089856

Permalink: https://www.biodiversitylibrary.org/partpdf/319093

\section{Holding Institution}

New York Botanical Garden, LuEsther T. Mertz Library

\section{Sponsored by}

BHL-SIL-FEDLINK

\section{Copyright \& Reuse}

Copyright Status: Public domain. The BHL considers that this work is no longer under copyright protection.

This document was created from content at the Biodiversity Heritage Library, the world's largest open access digital library for biodiversity literature and archives. Visit BHL at https://www.biodiversitylibrary.org. 